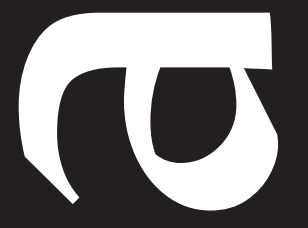

\title{
João Batista de Andrade
}
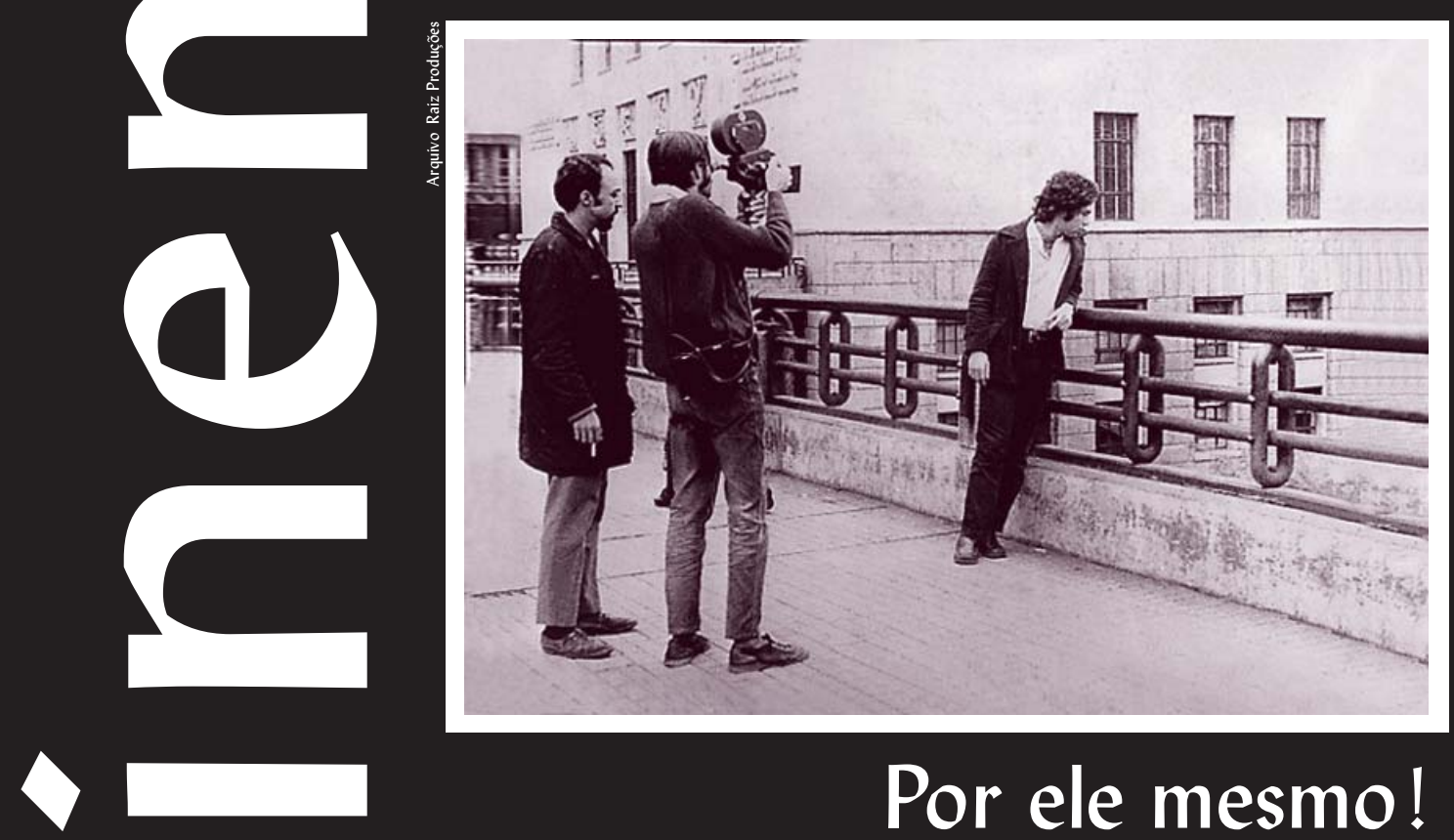

Por ele mesmo!

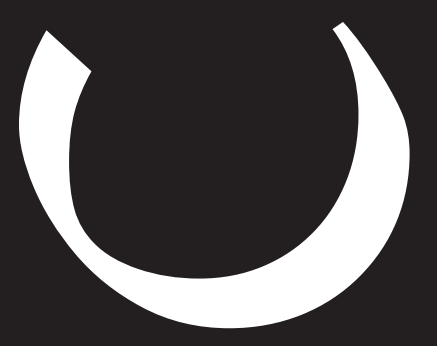




\section{Filmografia}

Direção de filmes de ficção

1969 Gamal, o delírio do sexo

O filho da televisão

1976 Alice

1977 Doramundo

1979 O homem que virou suco

1983 A próxima vítima

1986 O país dos tenentes

1996 O cego que gritava luz

1999 O tronco

2002 Rua $6, \mathrm{~s} / \mathrm{n}^{\circ}$

\section{Direção de ficção em vídeo}

1983 Dudu nasceu

\section{Direção de documentários}

1963 Catadores de lixo (inacabado) TNP - Teatro Nacional Popular (inacabado)

1966 Liberdade de imprensa

1967 Diversificação agrícola

1968 Portinari, um pintor de Brodósqui

1970 Paulicéia fantástica Gracias señor (inacabado)

1971 Eterna esperança

1975 Buraco da comadre Restos

1979 Greve! Trabalhadores: presentes!

1982 Tribunal Bertha Lutz

1985 Céu aberto

I99I Independência

\section{Direção de documentários em vídeo}

1981 A ferrovia do diabo

1988 Reforma administrativa

1998 Ontem, hoje, amanhã

\section{Direção de documentários para televisão}

1972 Migrantes

1973 Ônibus

Pedreira
1974 A escola de 40 mil ruas Eleições

1975 Vidreiros

Lenhador de automóveis

Paulo Vanzolini

O jogo de poder

1976 Batalha dos transportes

Viola contra guitarra

Mercúrio no pão de cada dia

$O$ grito em debate

Meningite

Desaparecidos

1977 Caso Norte

1978 Wilsinho Galiléia

I 98 I Por um lugar ao sol

1982 1932 / 1982 - A herença das idéias

1988 Cubatão urgente

\section{Montagem}

1963 Vila da Barca, de Renato Tapajós

1966 Universidade em crise, de Renato Tapajós

1971 Orgia, o homem que deu cria, de João Silvério Trevisan

\section{Direção de produção}

I 966 Mal de Chagas, de Francisco Ramalho Jr.

\section{Assistente de produção}

1967 Bebel, a garota propaganda, de Maurice Capovilla

\section{Produção executiva}

1968 Anuska, manequim e mulher, de Francisco Ramalho Jr.

1976 Tietê, um rio acaba na cidade, de Francisco Ramalho Jr. Rio Paraiba, de Reinaldo Volpato

Som

1966 Mal de Chagas, de Francisco Ramalho Jr. 


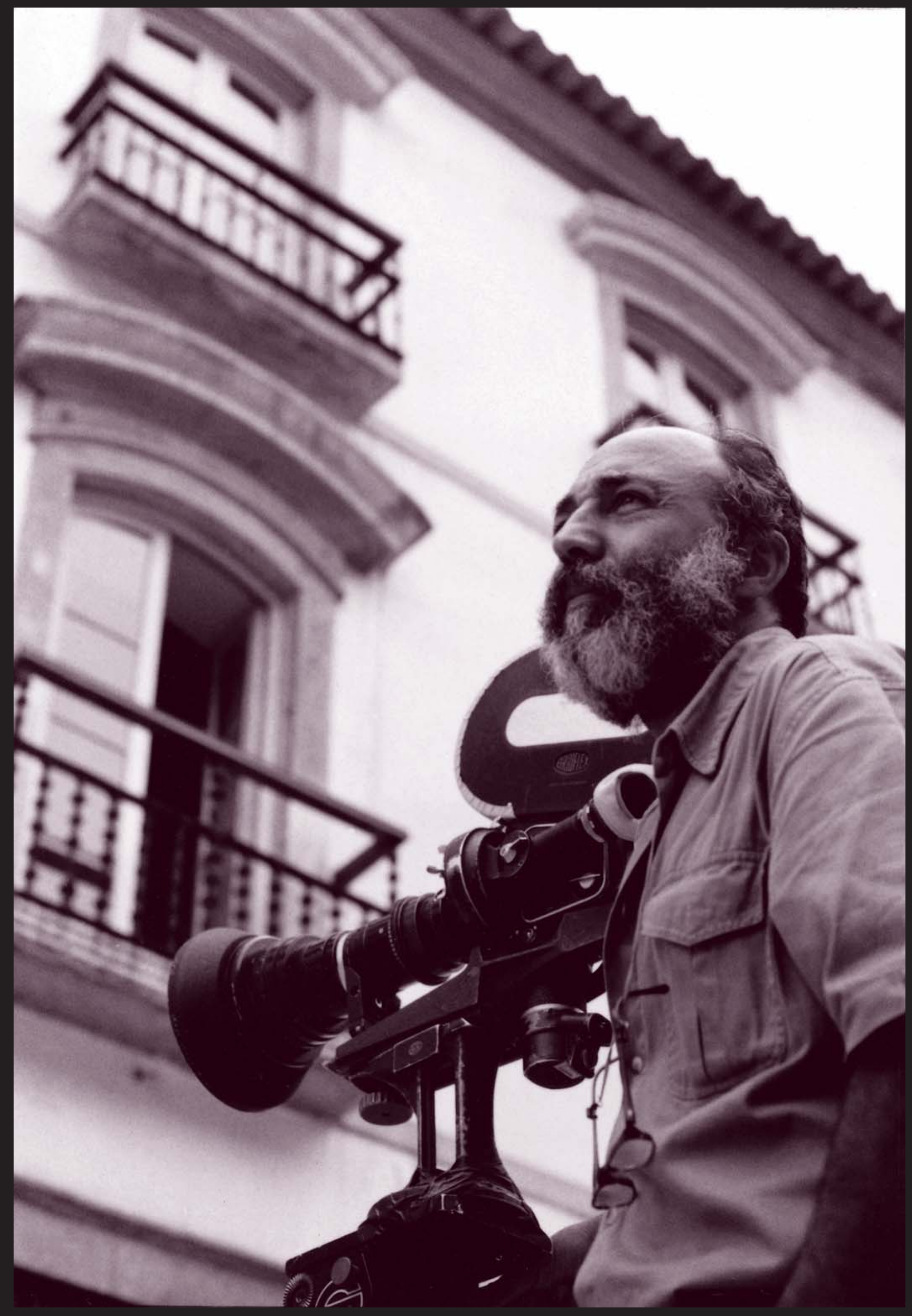




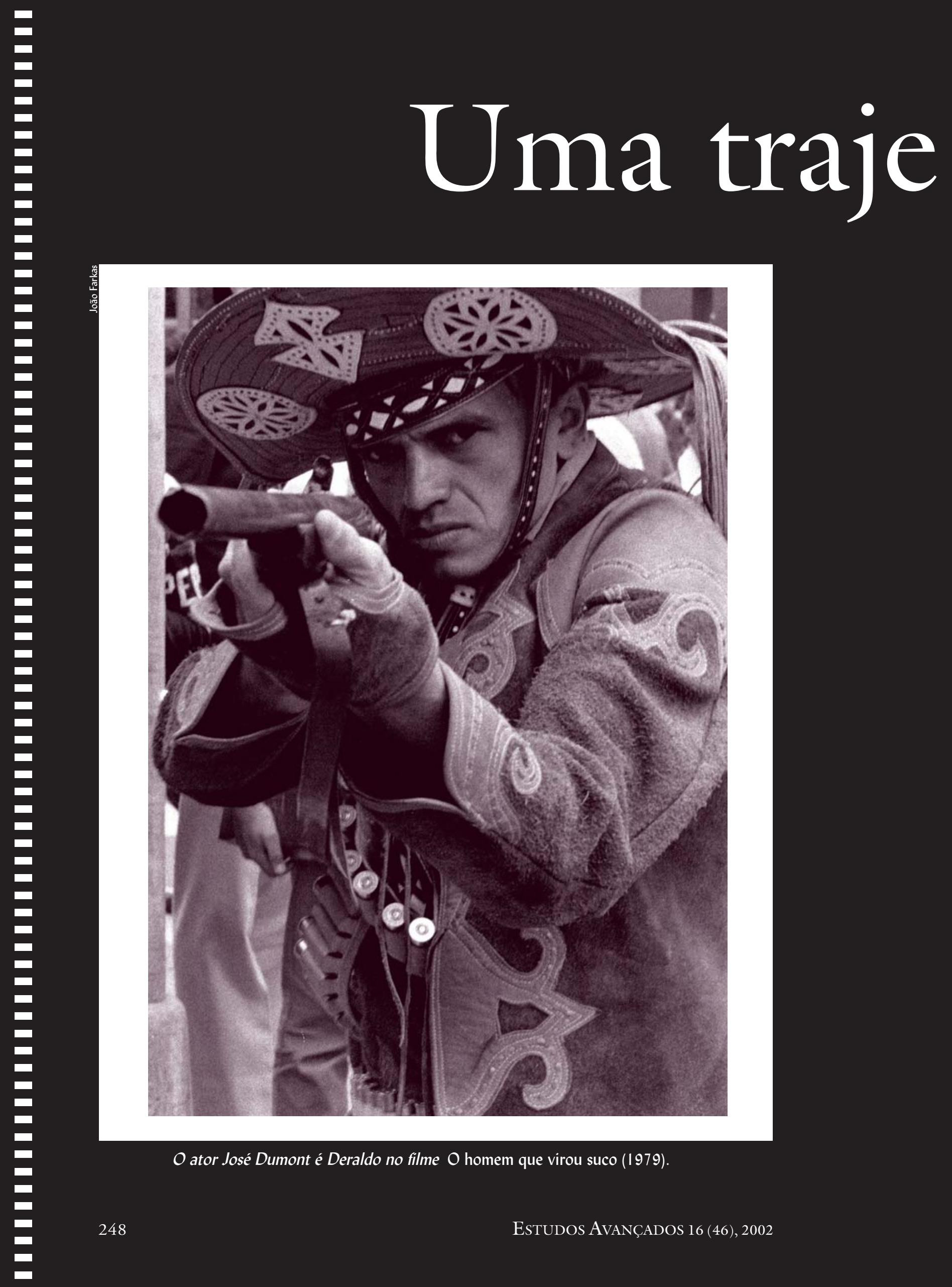




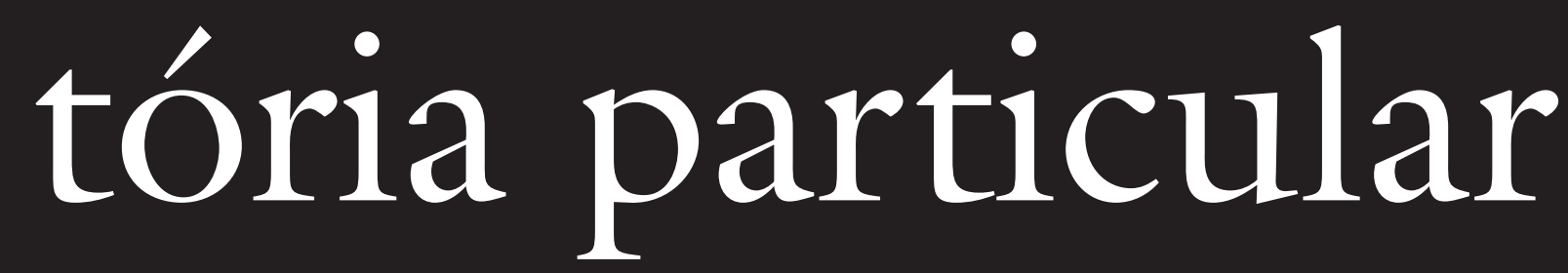

\section{JOÃO BATISTA DE ANDRADE}

$\mathrm{P}$ ERTO DE COMPLETAR os 40 anos de cinema - e quem sabe também pela experiência sexagenária de vida -, muitas vezes tenho tentado olhar para trás no afă de compreender melhor o que tem sido, de fato, a minha carreira como cineasta, de como o cinema marcou a minha vida, de como minha vida entrou cinema adentro. E, mais importante, o que dessa carreira atribulada - de muita luta, encontros, desencontros - tem de universal, de experiência aproveitável para outras pessoas, cineastas ou não. Uma coisa é certa e dela tenho tentado tirar muitas lições: sou de uma geração que se preparou, na primeira juventude, nos anos de 1950, para criar e produzir num país em progresso, confiante em seu futuro, democrático - aspiração que a História nos negou com bastante violência.

Nós nos preparamos na era juscelinista, acreditando na democracia, cultuando seus valores até no campo simbólico, como na construção de Brasília - e acreditando que o país podia sair do atraso, podia se livrar dos latifúndios e dos latifundiários, podia sair da ignorância e do analfabetismo, podia superar o grau quase insuportável de miséria da maioria de nosso povo. Ensaiamos um teatro crítico, viramos a música de ponta-cabeça, propusemos um cinema capaz de revelar a riqueza cultural e criticar as mazelas de nossa sociedade.

Minha geração acreditou nas idéias transformadoras, acreditou que elas agiriam sobre o real, modificando-o, empurrando o mundo para uma maior justiça, para o fim dos privilégios, para a democratização radical da sociedade. Era preciso ter, como parecia que tínhamos, no período de pelo menos uma década antes do golpe de 1964, um movimento social crescente gerando uma imagem nova do povo como força capaz de impulsionar nossa imaginação e para a qual poderíamos dirigir nossas idéias, nossas imagens, nossos textos e nossas inquietações. O povo aparecia, finalmente o povo, com o qual nós, jovens intelectuais, poderíamos realizar nossos projetos de futuro para a sociedade brasileira, afastando a velha imagem do país atrasado e inerme. 
Mas o destino, ou quem sabe a História, reservou-nos caminhos muito mais ásperos e tristes: o espaço brutal e redutor da ditadura militar por mais de 20 anos, desde 1964. A história de minha carreira pessoal - cujo valor não cabe a mim julgar - está marcada por essa circunstância da História. E valerá tanto por essa circunstância quanto pelos eventuais valores estéticos e humanistas encontráveis em meus filmes e livros.

Comecei a filmar em 1963, depois de ensaiar um caminho literário, escrevendo contos e até mesmo publicando, com alguns colegas, um jornalzinho literário na Casa do Estudante Politécnico. 1963 fora um ano de intensa agitação política e estudantil. E a Casa do Politécnico refletia isso, com um certo grau de loucura juvenil. Juntei-me a alguns colegas e criamos o chamado Grupo Kuatro, nome que denunciava o número de participantes mas exibia também a influência do grupo polonês KADR, de Kavalerovich e Wajda, cineastas críticos e de vanguarda, biscoitos finos do cinema de autor da época.

Como eu sempre digo para os jovens interessados em cinema, iniciar é fácil, basta ter vontade, basta querer. Isso porque ao iniciar tudo é permitido, tudo é invenção, tudo é novo. Difícil se torna depois, quando se passa da fase amadorística para a profissão, quando se resolve que o produto de nosso trabalho deve circular como uma mercadoria pela sociedade, transmitir informações, prazer, emoção. Aí as regras são mais duras, é preciso contar com o profissionalismo também de outras pessoas, equipamentos adequados e sempre caros, serviços técnicos, laboratórios - para que o resultado tenha condição de competir como produto cultural, isto é, que atinja o mercado, chegue ao público, realizando-se assim enquanto arte, viabilizandose enquanto produto.

O início de minha carreira teve exatamente essa liberdade, essa "facilidade" de bastar querer. Filmávamos praticamente sem dinheiro, com recursos mínimos de entidades como centros acadêmicos, União Estadual dos Estudantes, etc.; recursos que serviam para pagar o laboratório, comprar a película, sonorizar o filme. E nada mais.

Em 1966, fiz assim meu primeiro filme “solo", já desfeito o Grupo Kuatro e sob o regime militar que me forçara a deixar a Escola Politécnica por uns tempos. Consegui o patrocínio do Amanhã, jornal recém-criado pelo Raimundo Pereira para o movimento universitário, e também recursos do Grêmio da Faculdade de Filosofia, cujo presidente, Arantes, poucos anos depois, optaria pela luta armada e seria morto pelos militares. 


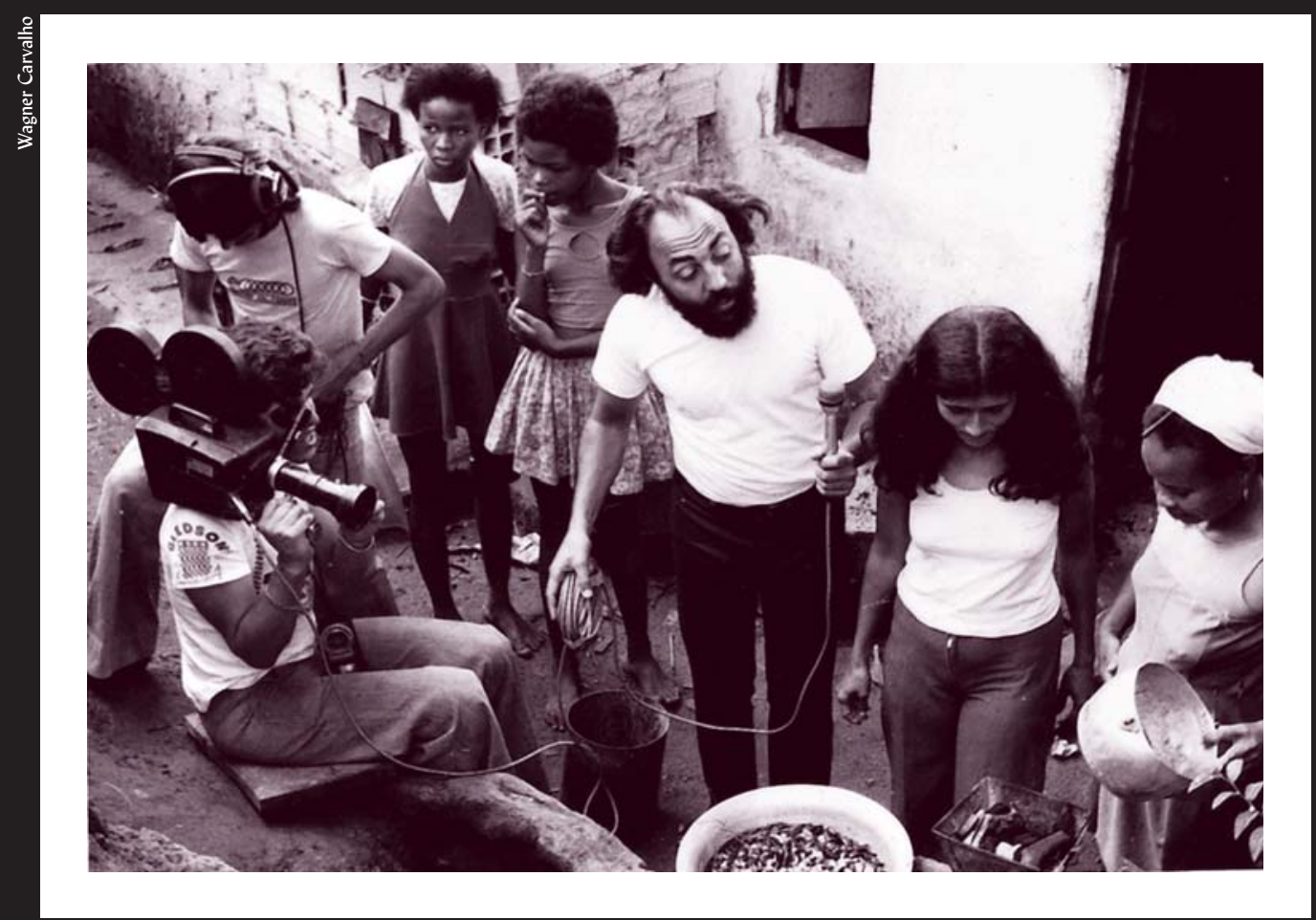

O diretor nas gravações de Mercúrio no pão de cada dia (1976), produzido pela TV Globo.

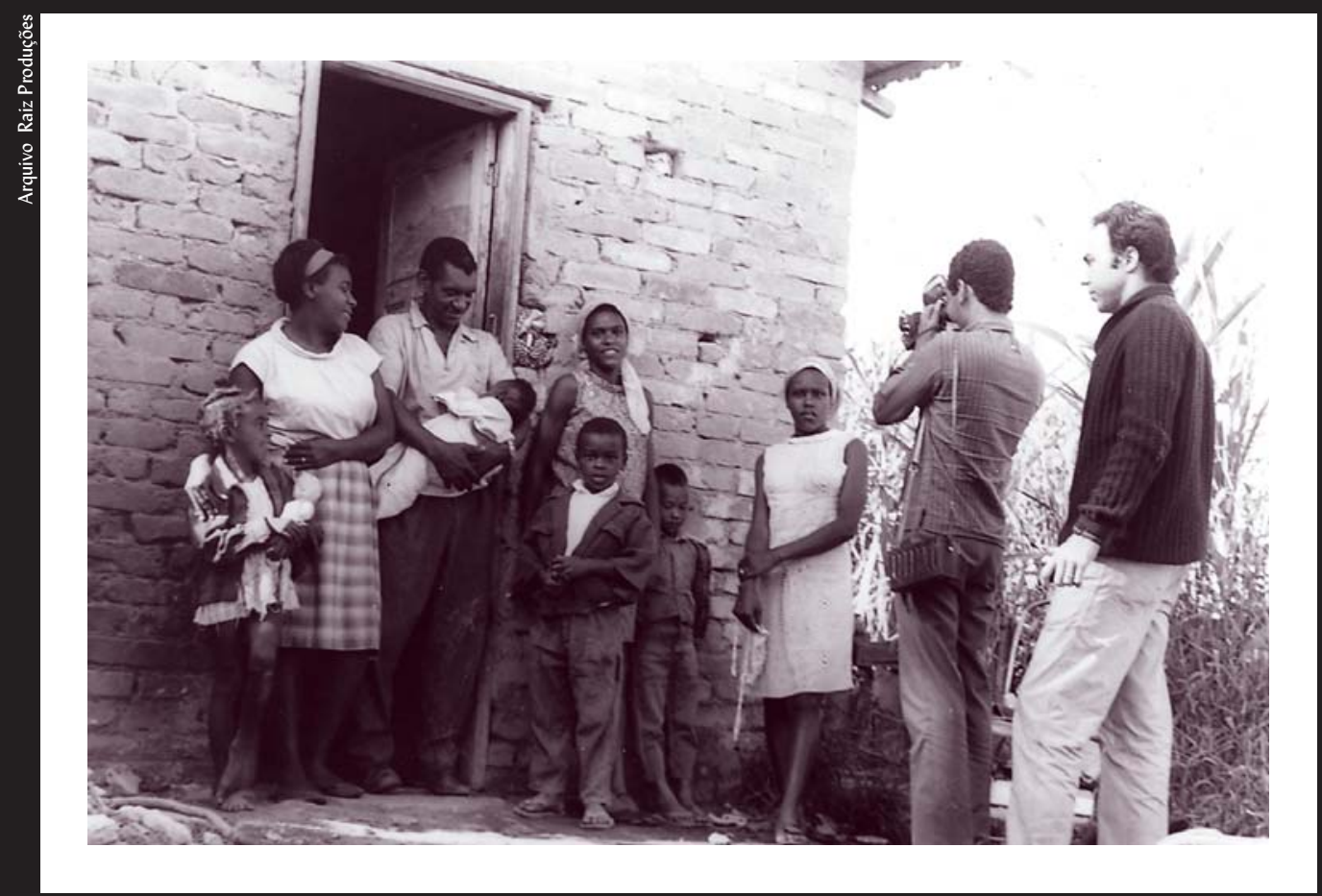

João Batista e Jorge Bodansky: o começo.

Estudos AvanÇAdOS 16 (46), 2002 


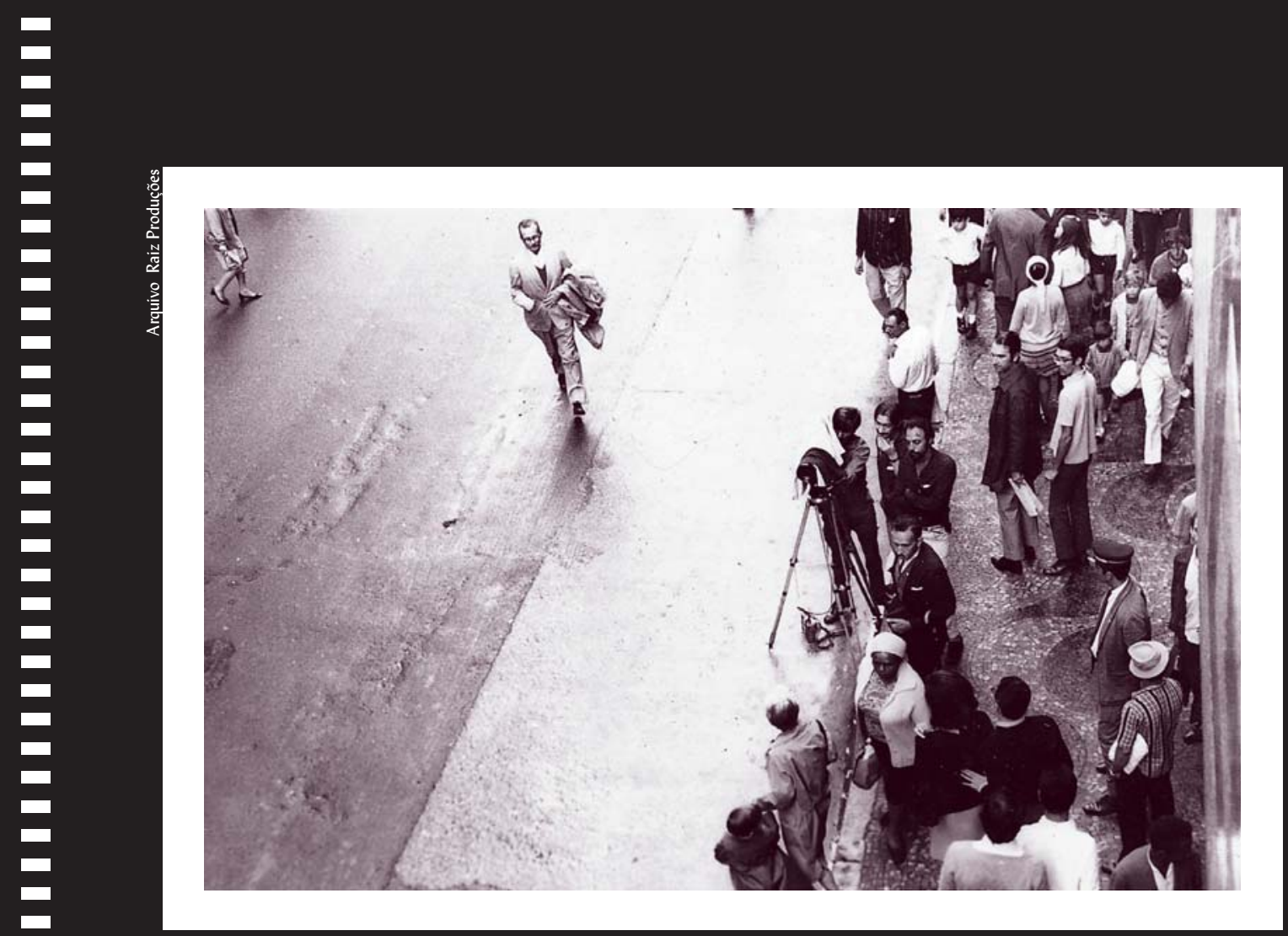

Liberdade de imprensa (1966): o filme de estréia...

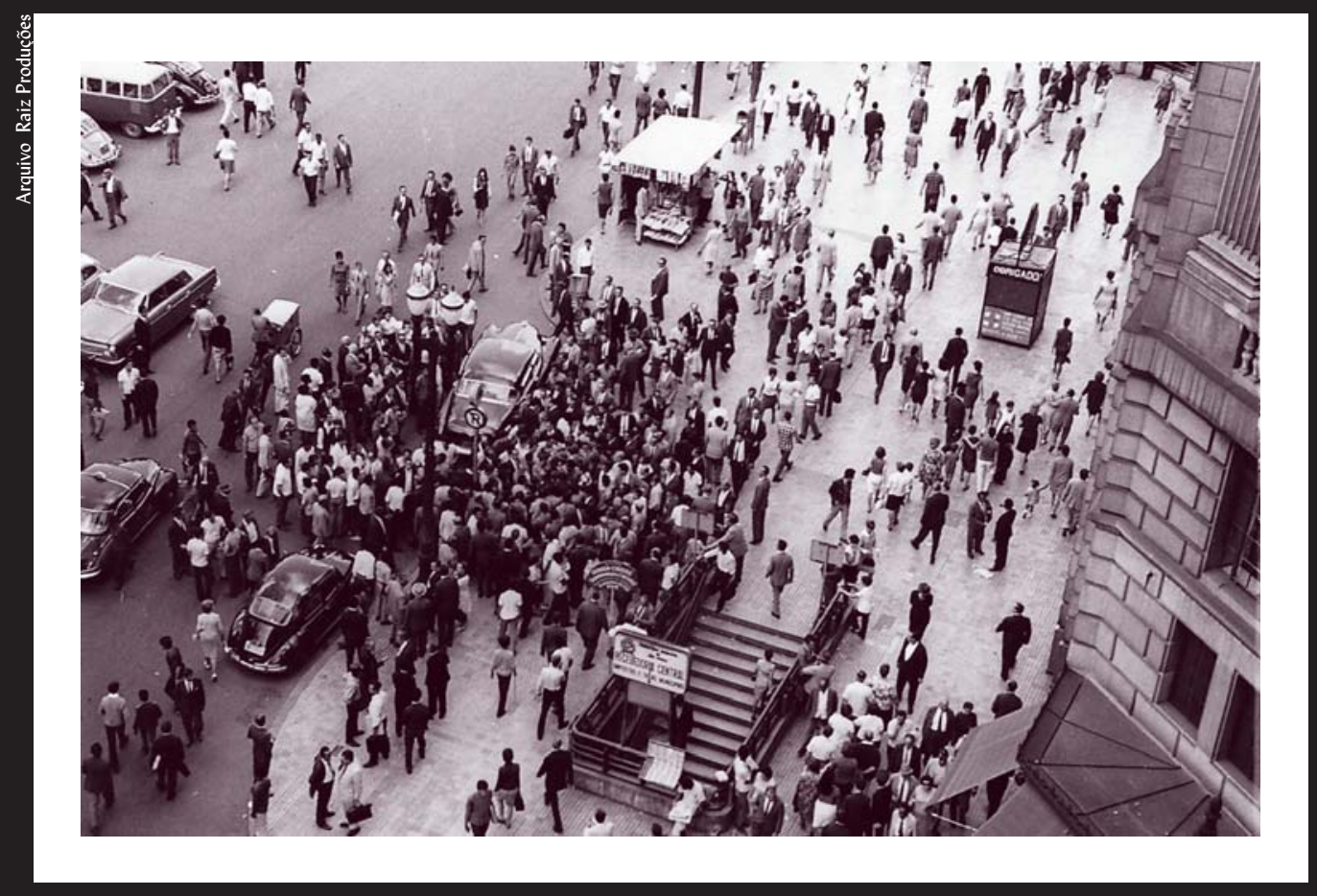

... foi apreendido pelo Exército no Congresso da UNE em I968. 
O filme é o Liberdade de imprensa que, mais uma vez pela injunção política da época, teve vida curta: exibido uma vez no Rio e outra em São Paulo, foi apreendido pelo Exército no Congresso da UNE em 1968, ficando praticamente desconhecido por mais de 20 anos, apesar de ser reconhecido hoje como um filme de vanguarda para a época e que apontava caminhos que só seriam seguidos na década seguinte.

Entre nós, jovens realizadores saídos do Grupo Kuatro, impunha-se um desafio a cumprir: o cinema brasileiro, apesar da ditadura, lutava por sobreviver, marcado positivamente pelos filmes e idéias do Cinema Novo, movimento que também sofreu duro golpe com a mal chamada "Revolução de 64 ".

Nós, de São Paulo, jovens aspirantes a cineastas, nos considerávamos uma espécie de cinema novo tardio, ao lado de mestres já reconhecidos como Roberto Santos e Luiz Sérgio Person, que funcionavam como espécies de guias de nosso movimento, sem esquecer as influências internacionais: Wajda, Kavalerovich, Francesco Rosi, Nagisa Oshima, todo o neorealismo, a nouvelle vague e o argentino Fernando Birri, de quem nos aproximamos por sua proposta de um cinema fortemente marcado pelas preocupações sociais.

Já fora da Universidade, muitos outros jovens foram se juntando a nós e, em 1968, criamos nossa primeira produtora profissional, a Tecla, onde estávamos Francisco Ramalho Jr., João Silvério Trevisan, Sidney Paiva Lopes e eu.

O mercado de cinema no Brasil da época, no final dos anos de 1960, tinha uma estrutura antiga, de poucas inovações, com circuitos dominados pelo filme americano, até mesmo pela ausência de uma produção contínua de nosso cinema capaz de ocupar e garantir a ocupação das salas nas capitais e no interior, onde ainda existiam grandes circuitos controlados por um pequeno número de pessoas e de difícil controle, que foram sendo desmantelados nos anos de 1970 pela concentração brutal de renda e pelo desinteresse das grandes distribuidoras norte-americanas.

A TV, no final dos anos de 1960, vinha se firmando como o principal veículo de comunicação no Brasil, primeiro com a Tupi e depois com a Globo. Novelas como $O$ diveito de nascer faziam um sucesso estrondoso. O protagonista, que fazia o médico dr. Albertino Limonta, era o ator Francisco Cuoco, que contava então como uma popularidade impressionante. E foi isso o que nos fez convidá-lo para nosso primeiro filme produzido pela Tecla: Anuska, projeto do Ramalho adaptado de um texto do Ignácio de Loyola Brandão. 
Ramalho achava que o projeto teria tudo de "comercial", ainda mais com o Francisco Cuoco, e que com o dinheiro da renda conseguiríamos fazer um outro projeto - o meu, mais político, com forte influência do Cinema Novo e do cinema do italiano Francesco Rosi (Ma no su la citá, O bandido Giuliano, O caso Mattei etc). O resultado, aliás bastante comum nesse tipo de projeto, foi no mínimo pífio, a ponto de o ator, que se tornara sócio do filme, desconfiar da seriedade de nossas contas. Mas as contas eram verdadeiras e o Anuska sequer se pagou. Isto é, não se transferiu para o filme o prodigioso sucesso do ator.

Esse tipo de tentativa repete-se ciclicamente no cinema brasileiro e chegou a dar certo nos anos de 1970, quando se queria tirar alguma vantagem do crescimento da TV, já que ela se negava sempre, como até hoje, a incorporar o cinema brasileiro em sua programação (salvo eventuais festivais, aliás sempre com muito sucesso). Agora chegava a vez das chamadas "pornochiques", filmes com conteúdo erótico e que expunham a nudez e a sensualidade de estrelas da TV. Produções como $A$ dama do lotação, que na verdade nada tinham de pornográficos, mas que, fazendo sucesso, eram recebidos com desprezo pela elite formadora de opinião.

$\mathrm{O}$ insucesso de Anuska afundou a Tecla e inviabilizou o meu projeto, jogando-me num desespero bem de época. Afinal, estávamos em 1968, sob o mando tenebroso do AI-5, com o aprofundamento da ditadura militar. Eu me recusava à luta armada, apesar do apelo de muitos amigos e ex-companheiros de militância política. E me recusava também a mergulhar no mundo das drogas, que consumia outros amigos.

Em meio a esse desespero, a essa falta de caminho, realizei dois filmes praticamente sem dinheiro, com atores de renome (Joana Fomm e Paulo César Pereio) que nem remunerados foram. E uma equipe disposta a transformar o ato de filmar num ato de rebeldia diante da ditadura e da inviabilidade, independente mesmo do conteúdo de cada filme. Assim fiz Em cada coração um punbal (episódio "O filho da TV") e Gamal, esse último super-hermético, influenciado pelo movimento underground, mas que me valeu o primeiro prêmio importante de minha carreira: o "Air-France", de Diretor Revelação.

Mantive por muito tempo um sentimento ambíguo com relação ao Gamal. A influência visível do chamado "udigrudi" (ou "marginal") brasileiro, um certo cinema desesperado e desestruturado, fezme estranhar a própria obra, enquanto o lado terrível, do medo, da 


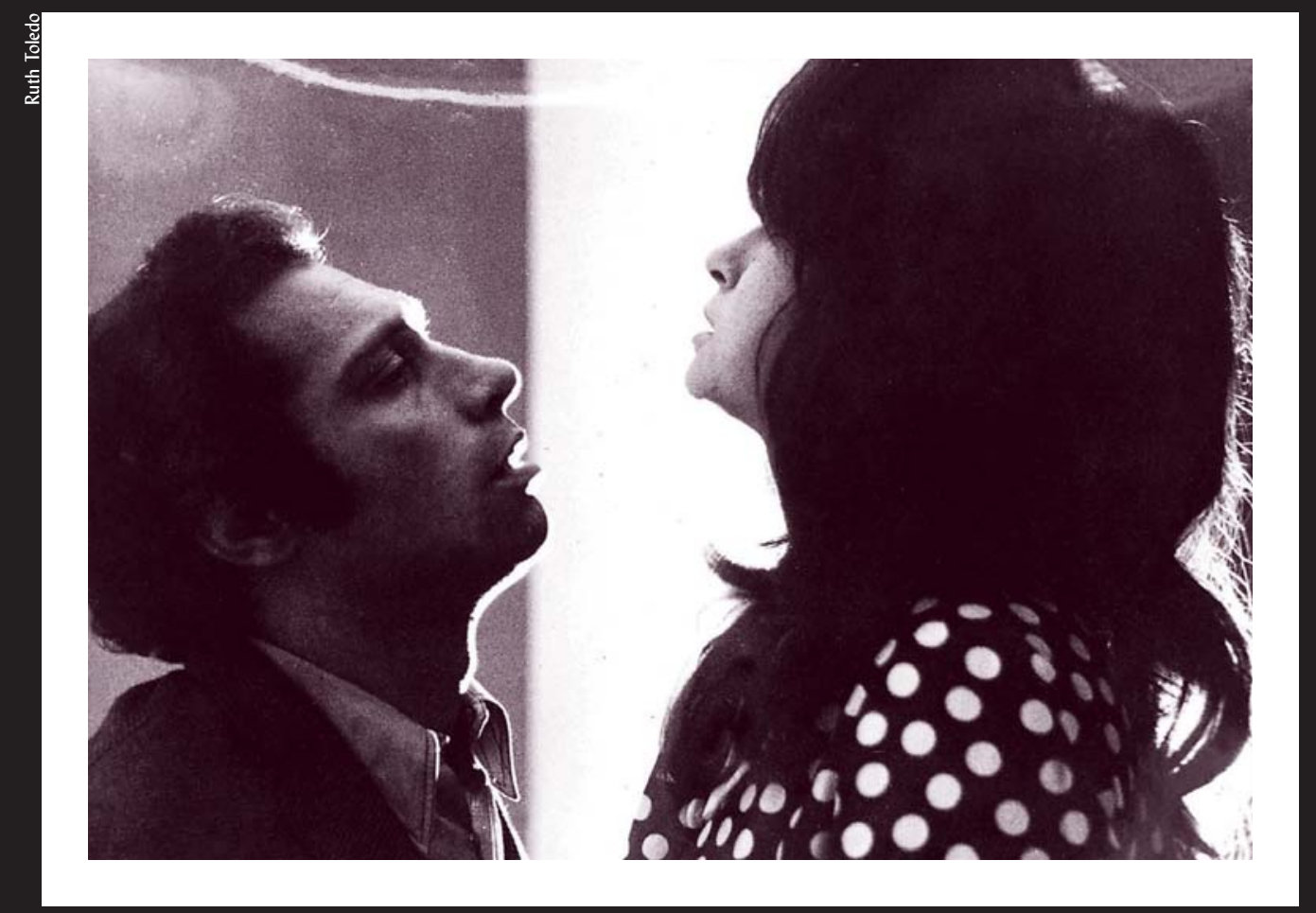

Em Gamal (1969), Paulo César Pereio e Joana Fomm "nem remunerados foram".

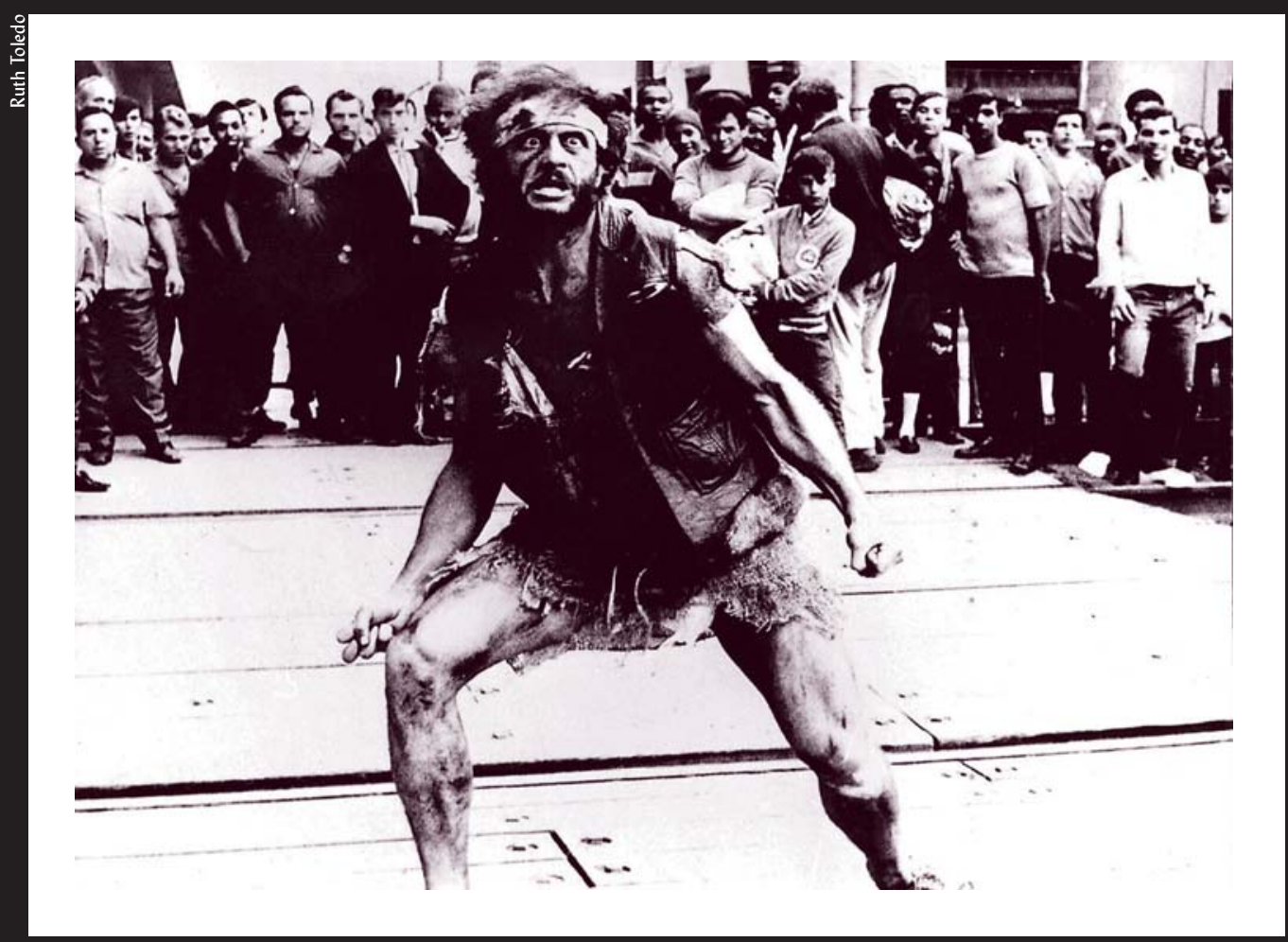

O ator Lourival Paris e a raiva impotente do personagem central do filme. 


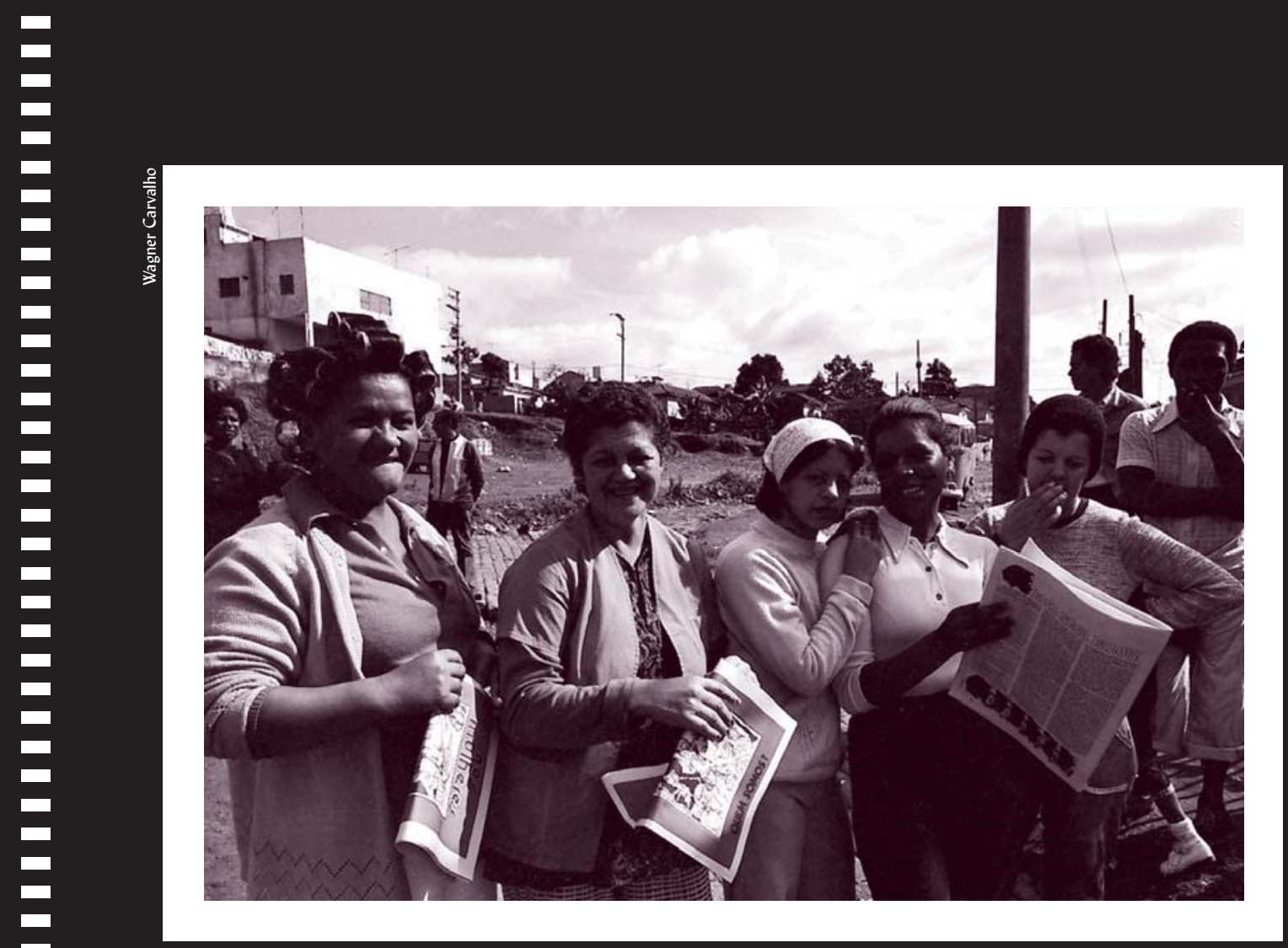

Documentário Buraco da comadre (1975): a falta de solução das autoridades.

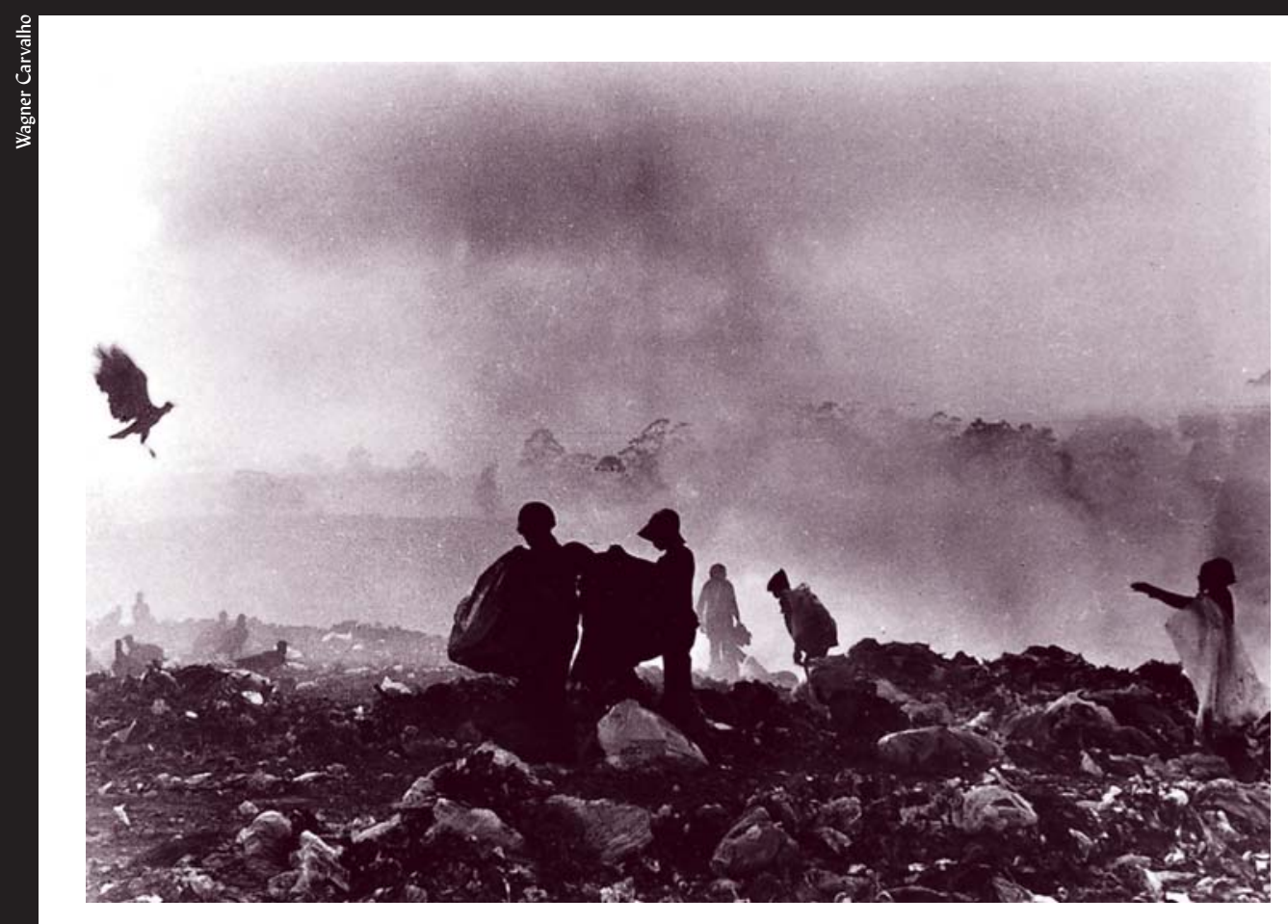

A beleza triste do lixão paulista no documentário Restos (1975). 
repressão, presentes na narrativa, denunciava minha ligação sensorial com o momento político e fazia do filme um objeto estranho também dentro do movimento "marginal". A verdade é que logo passei a rejeitá-lo, como uma obra que havia escapado a toda minha militância, ao meu racionalismo político. Por outro lado, eu sofria com essa condenação, vinda em primeiro lugar de amigos da esquerda e depois assumida por mim. É que eu via no filme, para além de uma certa confusão ideológica e política, uma beleza muito grande, um sofrimento muito grande, a indicação de um caminho muito pessoal que eu, antes de rejeitar, deveria explorar, mesmo que buscando de novo meu equilíbrio entre o artista e o político.

Mas essa seria uma postura que estava fora das minhas reflexões e de meus amigos do momento - erro que nos levou muitas vezes ao reducionismo e ao dirigismo. Basta ver o que aconteceu com o chamado "udigrudi", nomeação propositadamente pejorativa criada para denegrir um movimento que teve, alguns anos depois, vários de seus cineastas reconhecidos pelo público e pela crítica. Isso mostra a estreiteza política daquele tipo de condenação que confundia arte e ideologia, confusão que aparentemente fazia bem ao nosso sentimento militante mas que, na verdade, nos fazia muito mal.

No final dos anos de 1960, a cultura brasileira era marcada pela dor, pelo medo e pela confusão. Essa foi uma época terrível, não só pelos aspectos exteriores, a repressão, os assassinatos políticos, mas também pelos descaminhos, pela falta de perspectiva, a fuga generalizada. Fugia-se do país, fugia-se da compreensão, fugíamos de nós mesmos. Fugíamos para o desespero, para o desencanto, para a aventura armada, fugia-se para as drogas.

O cinema dessa época é uma espécie de testemunho sofrido desse coquetel ruim que nos fez tanto mal. Um cinema de gritos, imagens enigmáticas e que dialogava consigo mesmo, muito distante da batalha libertadora que sonhamos um dia unir intelectuais e povo numa verdadeira revolução, agora, perdida.

A compreensão desse momento, e a vontade de sair dele, fez-me buscar um outro caminho. O prêmio Air-France por Gamal, apesar de tudo, fez-me bem e ainda me deu uma viagem à França. Em Paris e Roma, em 1971, fiz contatos com velhos amigos, militantes de esquerda de todas as matizes. Muitos desses exilados, a essa altura, com a guerrilha brasileira já derrotada, reviam sua posição quanto à luta armada e colocavam a questão democrática. Isso reacendeu em mim a vontade de voltar a filmar, retomar meu caminho deixado para trás 
desde o Liberdade de imprensa. Pensei então que eu deveria filmar o Brasil real, uma idéia documentária capaz de se contrapor à imagem de paz e tranqüilidade forjada pela ditadura nos meios de comunicação, tanto pela censura quanto pelos famosos filmezinhos institucionais que exibiam o país como uma ilha de paz em meio a um mundo conturbado por greves e crises políticas e sociais.

Para se ver que essa idéia de voltar ao país real era um acontecimento coletivo, meu desejo coincidiu com o projeto dos jornalistas Fernando Pacheco Jordão e Vladmir Herzog, o Vlado, que me convidaram para fazer exatamente isso num programa jornalístico da TV Cultura, o "Hora da Notícia", que estava sendo criado naquele momento. Eu sempre repito que minha passagem por esse programa talvez seja o momento mais rico de minha vida como cineasta e cidadão: quando eu buscaria realizar, sendo cineasta, minha visão crítica como cidadão, a militância antiditadura.

Meu trabalho era realizar, diariamente, pequenos documentários para os quais eu procurava direcionar a minha inquietação: questionar, exibir as imagens que a ditadura ocultava, ousar, fazer o telespectador tomar consciência do país real em que vivia. Procurava, assim, escapar do embuste visual da ditadura e da visão preconceituosa da classe média brasileira formada nos anos do "milagre brasileiro". Um exemplo desse trabalho é o Migrantes, que recuperei como filme, depois de ter ido ao ar em nosso programa.

Migrantes partia da leitura de uma reportagem de primeira página de um jornal paulista: moradores do Parque Dom Pedro reclamavam da presença de "marginais" sob o viaduto. Minha leitura era outra e fui filmar. Debaixo do viaduto minha câmera encontra uma família de migrantes fugindo do desemprego no Nordeste. Vendo um paulistano tipo executivo assistir à filmagem, imaginei do quanto de preconceito ele estaria impregnado e, sem nada dizer, dirigi o microfone para ele. O diálogo dos dois - o paulistano engravatado e o migrante - é o núcleo revelador da obra, que acabou vencendo como Melhor Filme no Festival de Documentários de Salvador, em 1973.

No início dos anos de 1970, como parte da desorganização geral da cultura brasileira, o cinema brasileiro parecia morto e, quando vivo, degradado na forma erótica que se apossou do cinema comercial da "boca do lixo" carioca e a paulista. Nada a ver com o cinema de idéias do início dos anos de 1960: ele se rendia ao niilismo e à exploração do sexo, o que marcou profundamente a imagem que o público passou a ter sobre nosso cinema. 


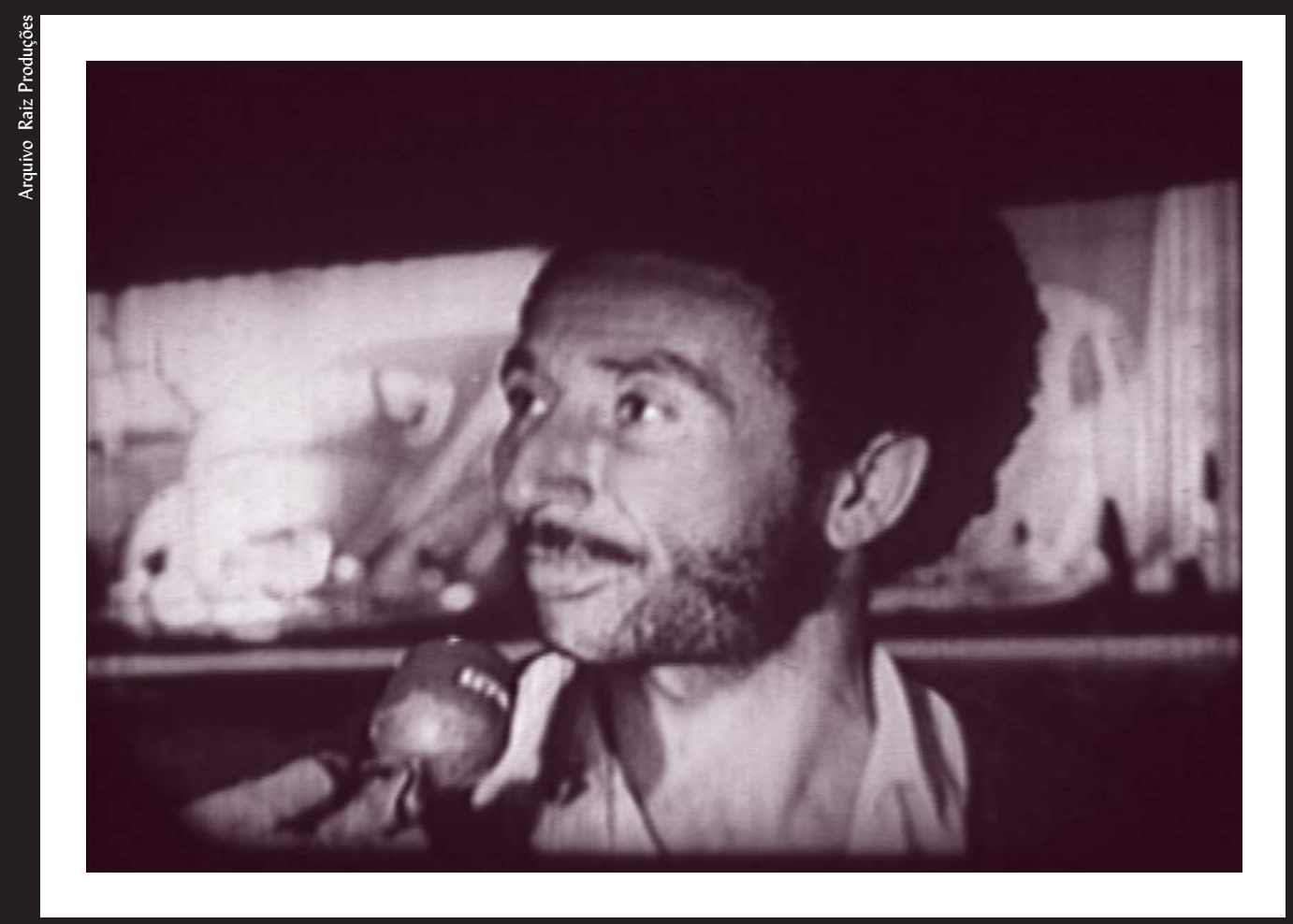

Em Migrantes (1972), Sebastião defende seus direitos e sua individualidade.

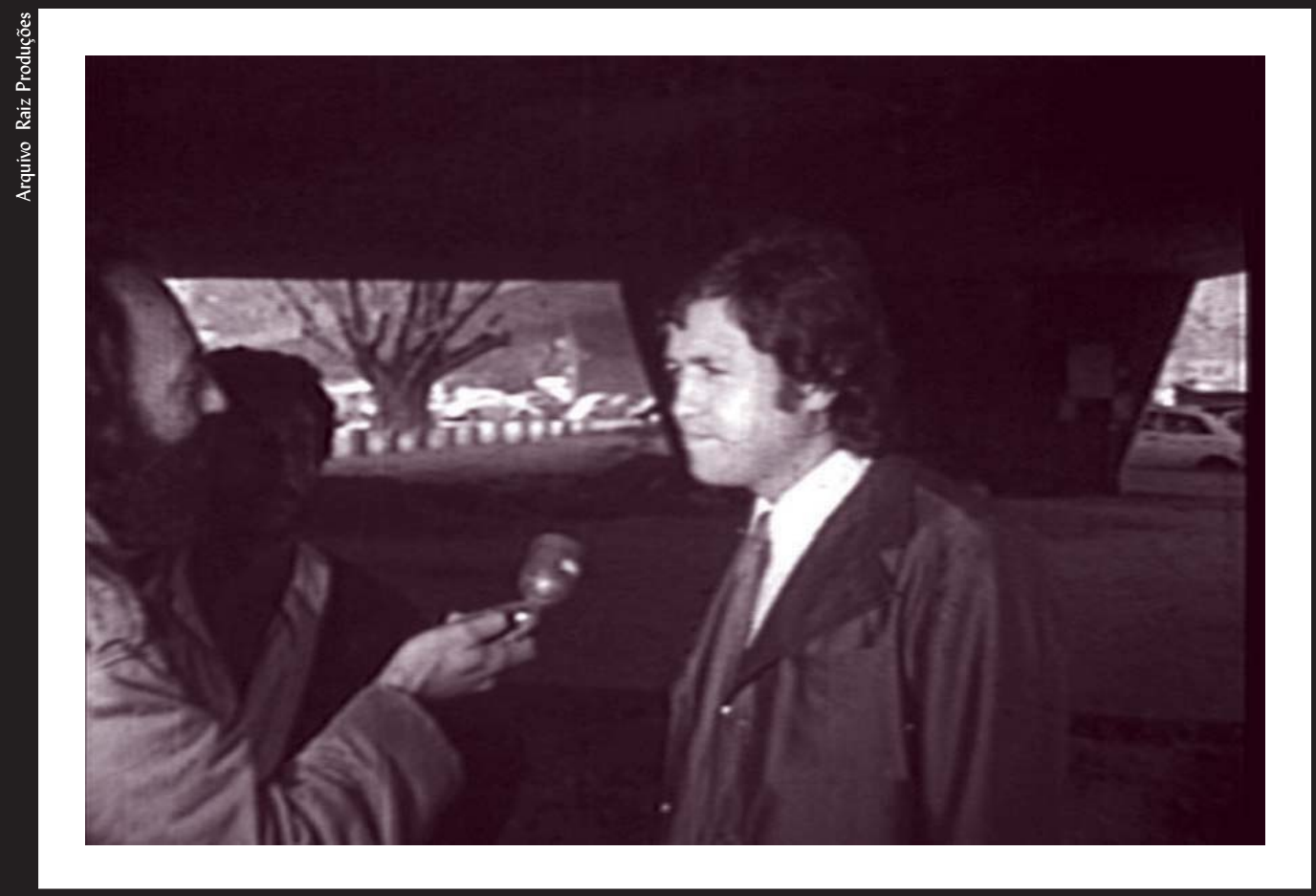

"Sem nada dizer, dirigi o microfone para ele": dramaturgia da intervenção. 


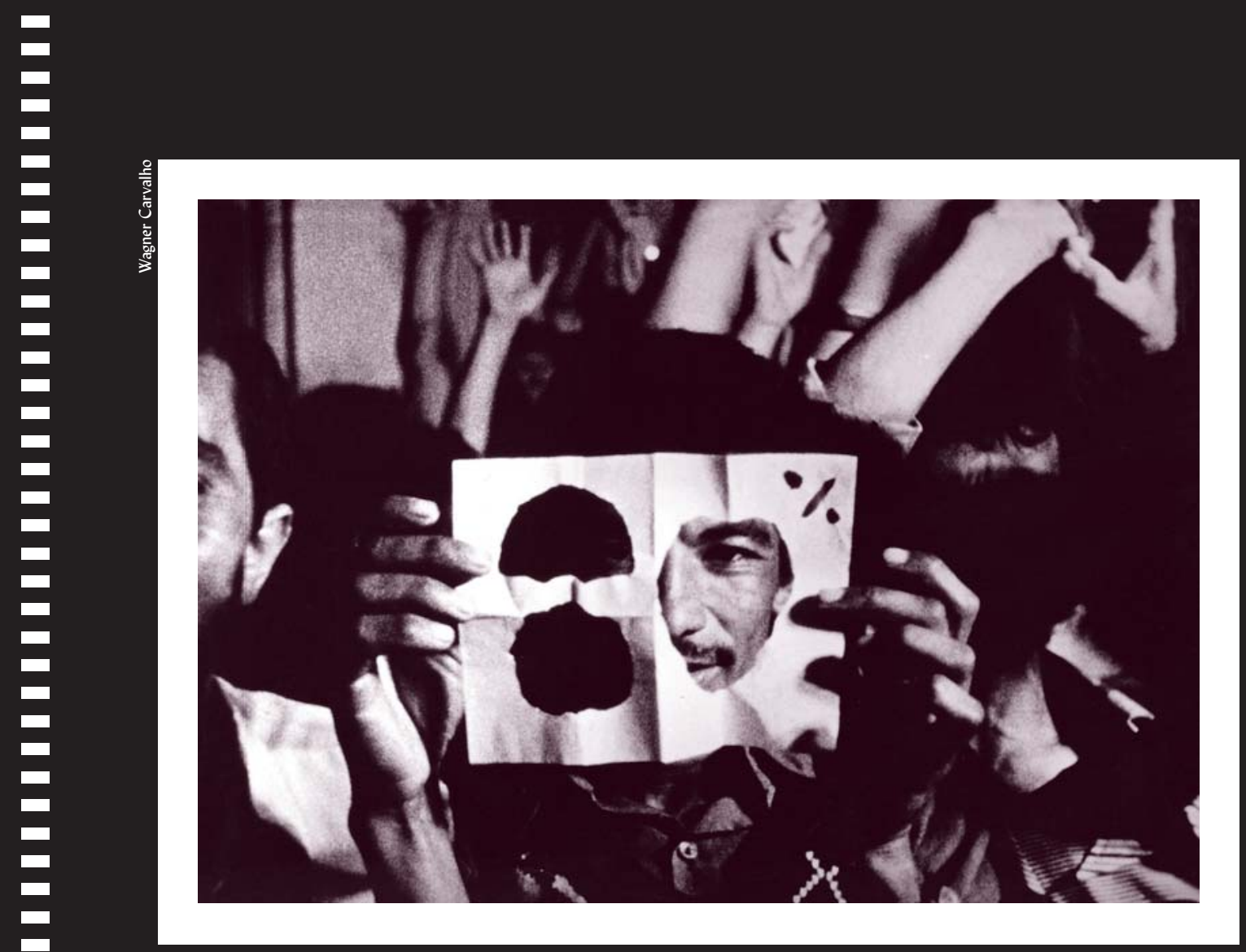

Trabalhadores: presentes! (1979): por trás da reivindicação, o rosto do trabalhador.

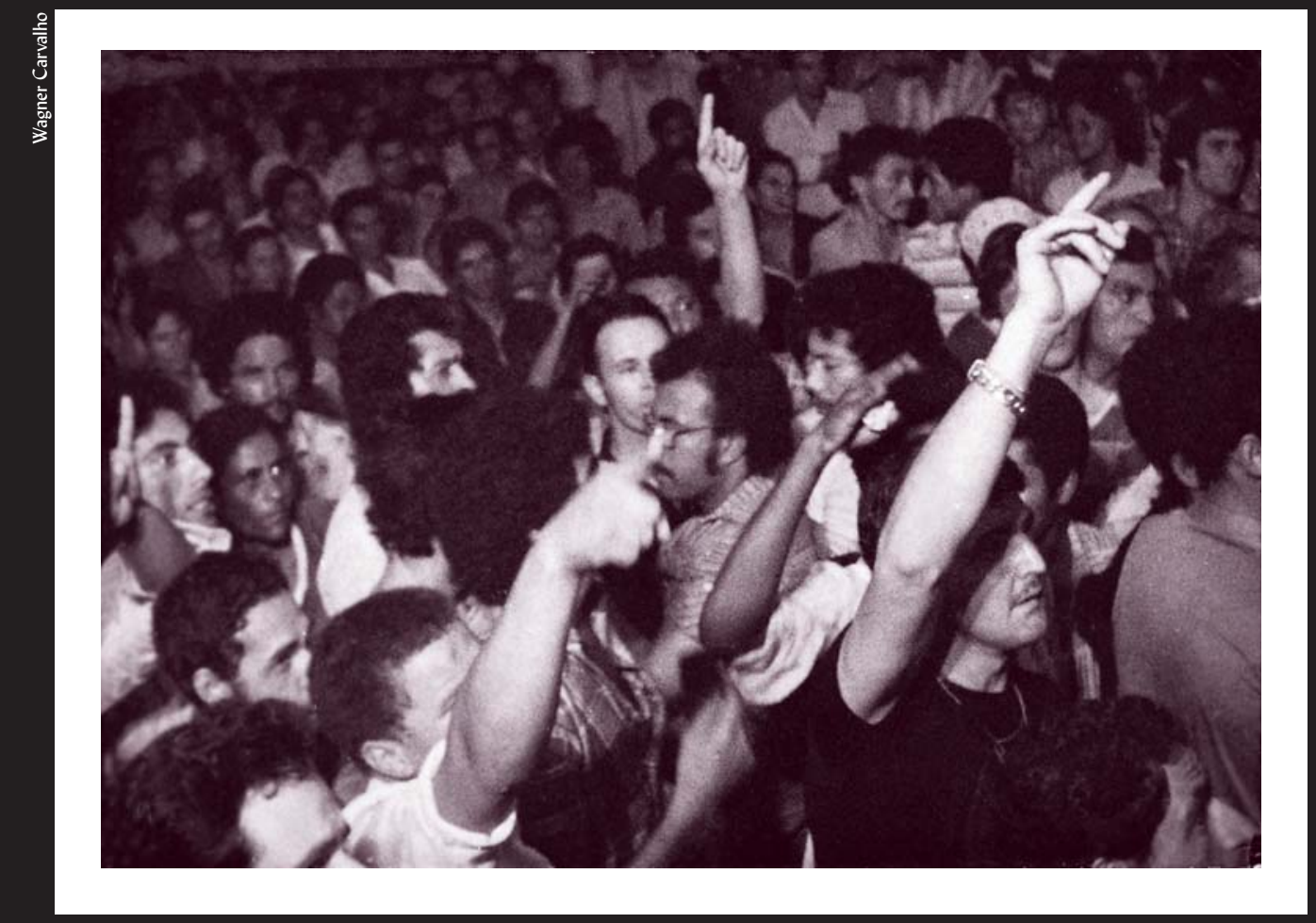

Greve! (1979): documento histórico e opinativo do diretor. 
Sempre achei o cinema chamado de "pornochanchada" interessante; eram filmes no fundo inocentes e que falavam, com muito humor, do sexo na vida cotidiana da classe média brasileira. A deterioração desse gênero, rumo ao sexo explícito, e o fim do espírito narrativo nos filmes vêm também pela pressão exercida pelos exibidores que, em plena ditadura (e talvez por isso mesmo), traziam a enxurrada de pornografia cinematográfica internacional com grande sucesso de público logo no início dos anos de 1970.

É nessa época que se articula a criação de uma nova política para o cinema brasileiro, com um surpreendente apoio governamental, apesar da ditadura e de que o regime militar incentivava, com tudo o que podia, o crescimento das redes de TV como instrumento de unidade nacional e formação ideológica. É estranho que, mesmo assim, tenha desenvolvido um projeto tão ambicioso quanto o que criou a Embrafilme e o Concine: o primeiro para agir sobre a produção e o mercado, o segundo para legislar e controlar a atividade cinematográfica no país. E tudo isso com imensos atritos com o cinema norte-americano, que derrapavam sistematicamente para as áreas de governo dos dois países.

Há muitos estudos sobre a Embrafilme e também críticas estapafúrdias do tipo "os cineastas negociaram com a ditadura", facilidade de análise que não condiz com a carga crítica de nossos cineastas e filmes. A verdade é que uma brecha se criou ali, no início da idéia de abertura política, quem sabe alimentada por um certo nacionalismo do regime, mas também por certos acasos, como o interesse do ministro Ney Braga e do poderoso ministro do Planejamento, João Paulo dos Reis Veloso.

A Embrafilme, tirando seus muitos defeitos, representava um avanço, ao sistematizar um modelo de financiamento e enfrentar o dragão do mercado. O sucesso, na verdade, é que a tornou obsoleta, incapaz de se atualizar para fortalecer o cinema como atividade profissional independente do Estado, sedimentar a ligação cinema-mercado em contraposição ao nosso evidente voluntarismo autoral, que só poderia sobreviver com permanentes injeções de recursos governamentais. Não que se devesse perder um certo experimentalismo autoral, mas essa liberdade poderia estar na "periferia" do cinema de mercado, com incentivos, prêmios, concursos etc. Os tempos mudavam, o Estado tendia a se liberalizar, sair das áreas produtivas e o cinema brasileiro ainda estava preso, sem alternativas, ao velho modelo estatal. 
Nos primeiros anos da Embrafilme, eu ainda estava na TV. Com o fim do "Hora da Notícia", da TV Cultura, vítima da perseguição política, fui convidado pela Globo para criar, em São Paulo, um setor de reportagens especiais. Em fins de 1974, os ventos pareciam mudar um pouco de rumo, abrindo novas possibilidades com a extremamente controlada "abertura" anunciada e depois conduzida com mãode-ferro pelo general Ernesto Geisel.

Na Globo, tentei seguir o caminho aberto na TV Cultura: uma linha documental na qual o importante seria continuar revelando o país real em que vivíamos, abordando temas os mais críticos possíveis para o momento. Meus primeiros filmes tiveram dificuldade em serem programados. Em parte, pelo seu teor crítico (um sobre menores delinqüentes e outro sobre a miséria do transporte urbano popular em São Paulo) e, em parte, porque estávamos em pleno processo eleitoral, o que tornava o controle da censura mais agudo, mais terrível. Passadas as eleições, os dois filmes foram ao ar, com ótima repercussão. Um deles, $A$ escola de 40.000 ruas, chegou a ser convidado para o principal festival internacional de documentários, o de Oberhausen, na Alemanha. O título do filme foi usado logo depois numa capa de Veja, com matéria sobre a questão dos menores de rua.

A partir daí tudo parecia mais fácil, apesar dos controles costumeiros da censura e da própria empresa. O "Globo Repórter", então nas mãos de cineastas (Paulo Gil Soares, Maurice Capovilla, Hermano Penna, Eduardo Coutinho, Walter Lima e eu), era um programa de grande prestígio e audiência, o que provava, mais uma vez, que os cineastas brasileiros tinham capacidade de comunicação com o nosso público, desde que abertos os canais de acesso a esse público.

Estávamos em pleno processo de abertura política, passado o trauma pessoal e nacional do assassinato de Vladmir Herzog, meu amigo e companheiro Vlado. A própria reação pública a essa violência mostrou que a sociedade brasileira já não suportava mais a ditadura e que a abertura era inevitável, com ou sem a benevolência dos militares.

Mas nem tudo eram rosas. Em 1978, fiz um filme de sucesso para o "Globo Repórter", chamado Caso Norte, ensaiando um novo tipo de documentário mesclado de ficção, com atores. O sucesso do programa me abriu novas portas, e eu achava mesmo que, diante da abertura política, era preciso avançar os temas e os tratamentos de nossos filmes, sob pena de ficarmos atrás do próprio cotidiano das TVs que, aos poucos, iam se abrindo para os fragmentos da vida real brasileira, seja nos noticiários, seja nas telenovelas. 


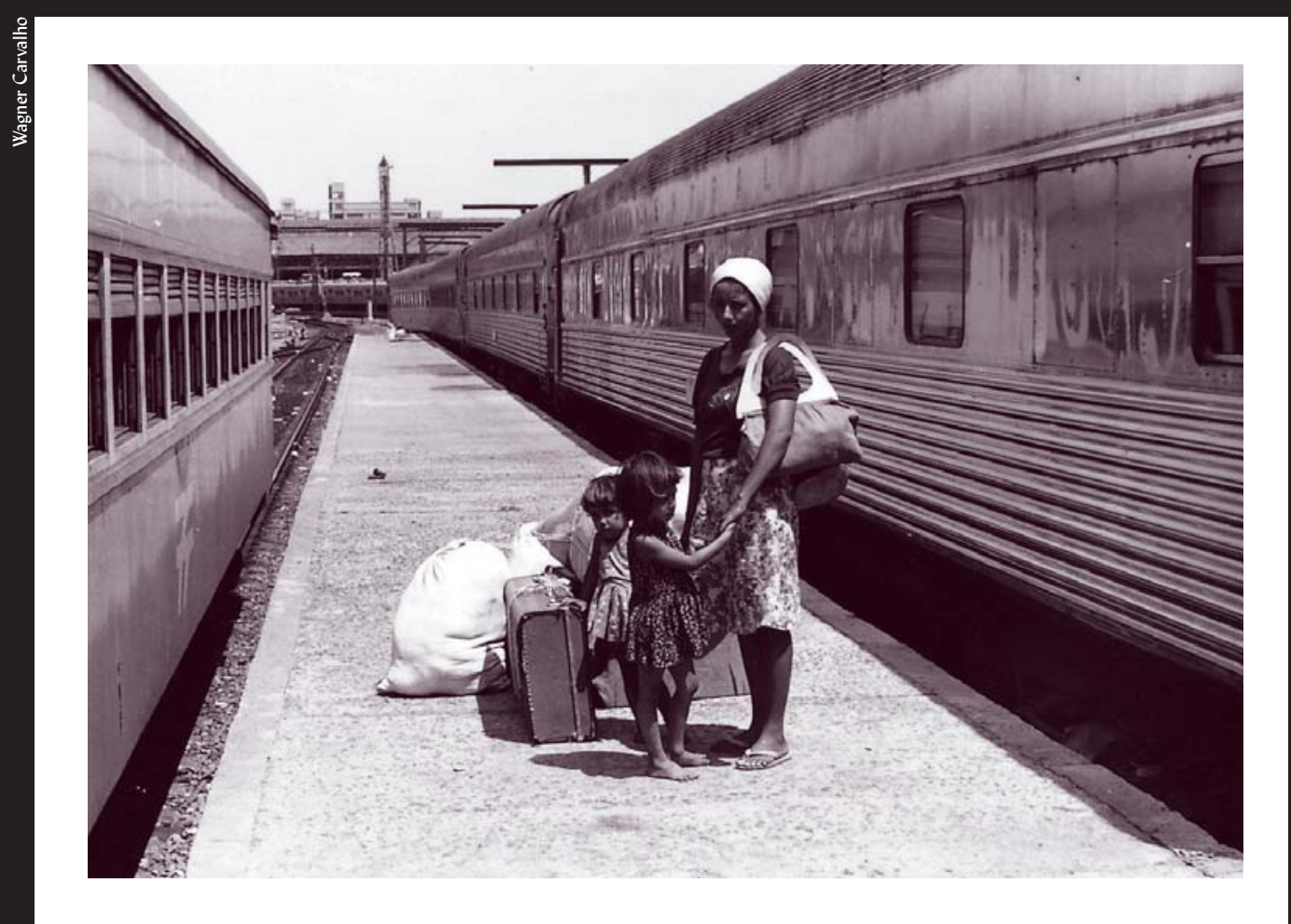

No documentário Caso Norte (1977), a chegada de migrantes.

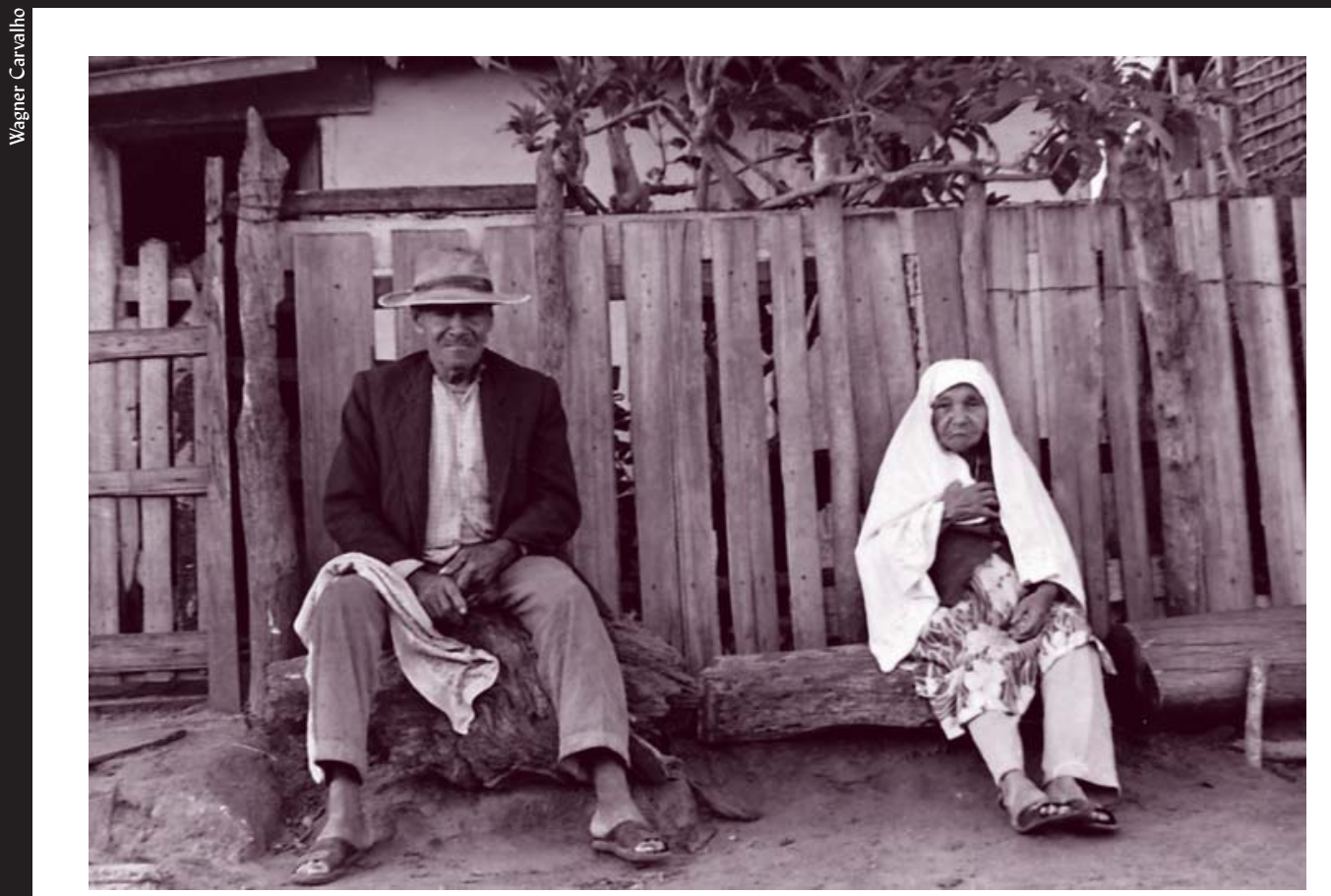

Em Viola contra guitarra (1976), a investigação do que é o progresso na cidade do interior. 


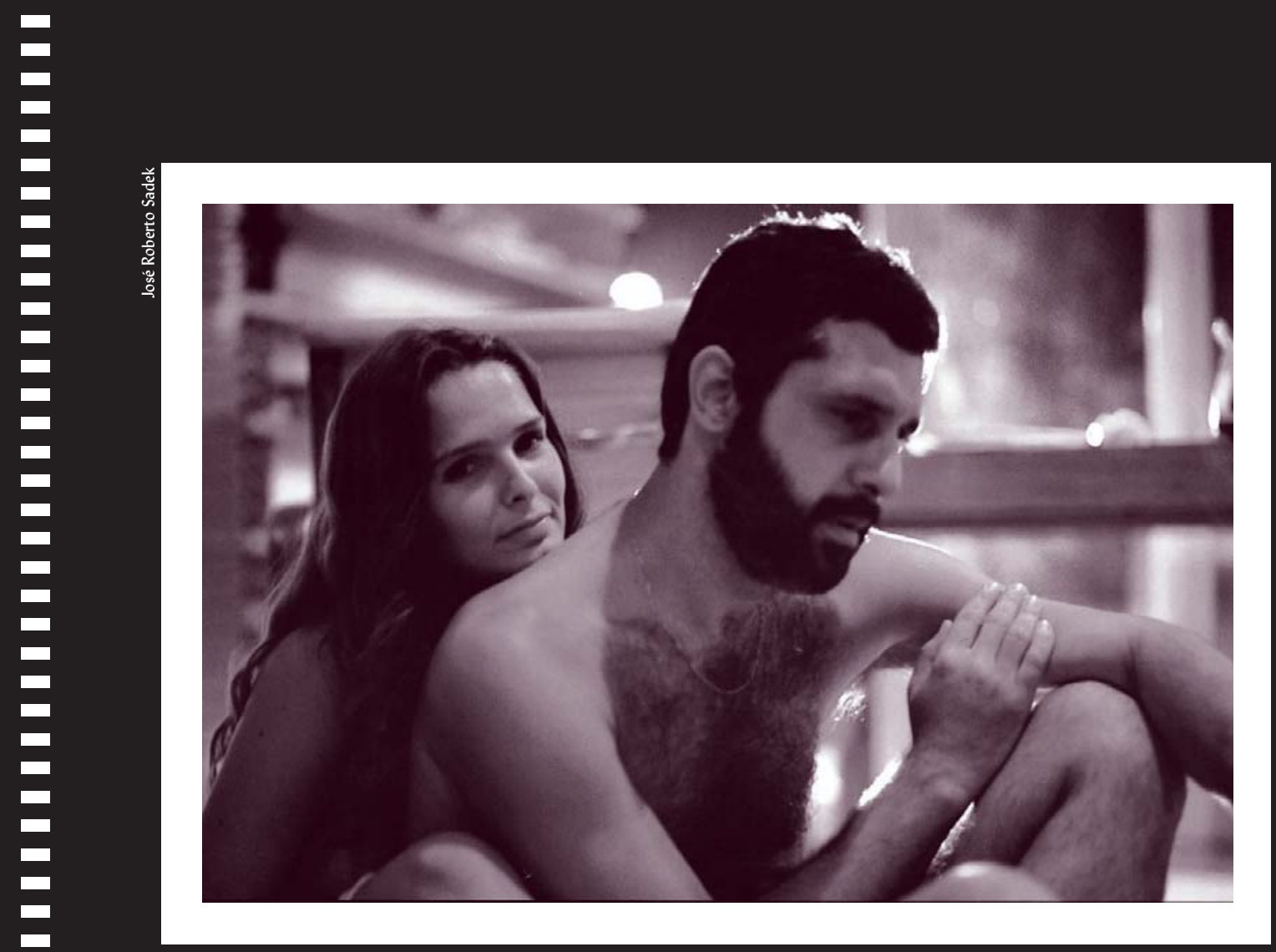

Louise Cardoso e Antonio Fagundes em A próxima vítima (1983).

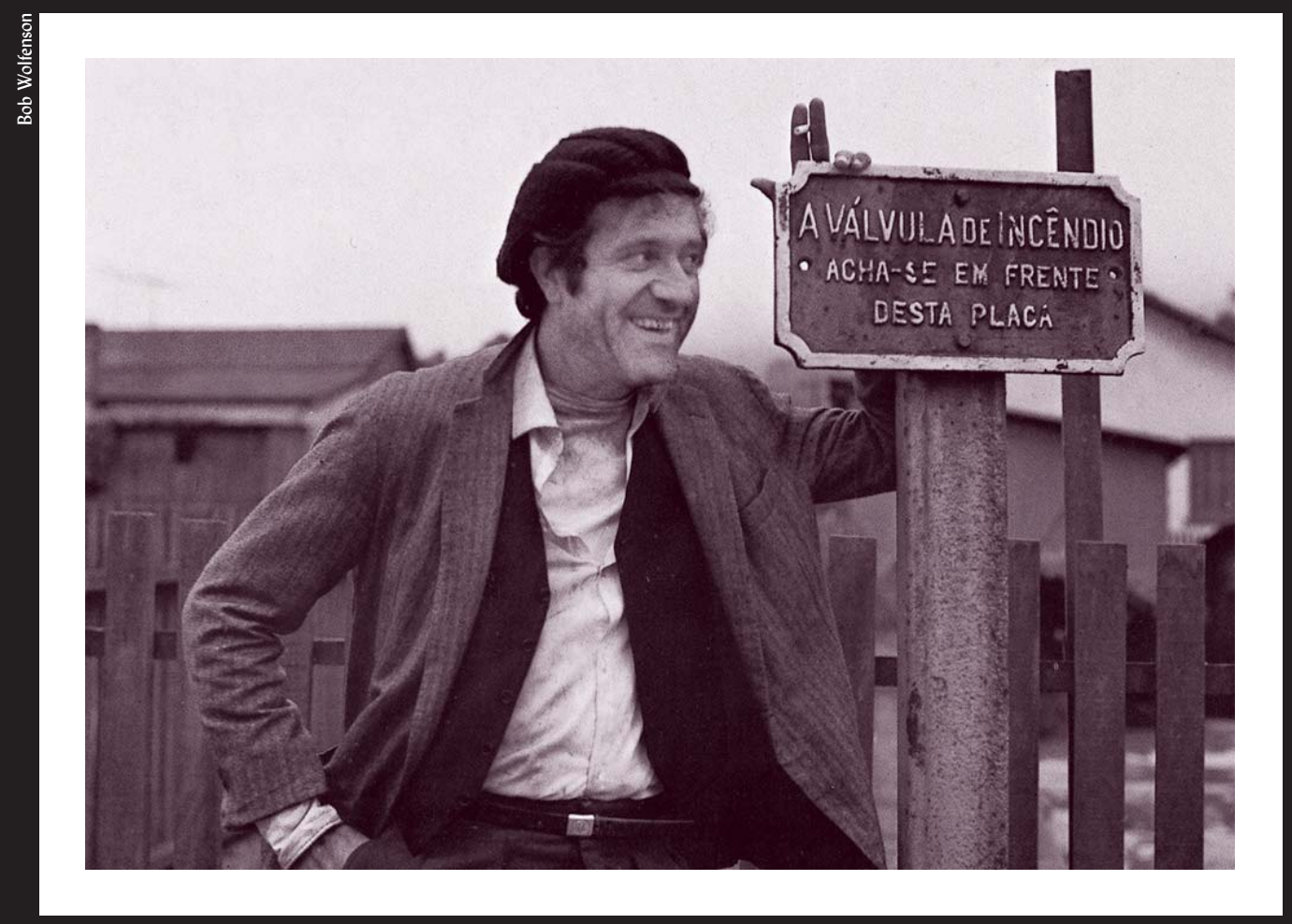

Doramundo (1977): Rolando Boldrin, em seu primeiro filme. 
Entusiasmado, fiz o segundo filme do modelo iniciado em Caso Norte, o longa-metragem Wilsinho Galiléia, sobre a questão dos menores delinqüientes e que seria exibido em dois programas do "Globo Repórter”, em 1978. O filme recriava a trajetória triste e trágica do menino Wilson Paulino até a sua morte, fuzilado pela polícia ao completar 18 anos. Numa evidente demonstração de que a ditadura ainda estava ali, mesmo que morrendo, o filme foi proibido pela censura e só agora, 24 anos depois, vem sendo visto e reconhecido. No dizer da crítica Maria do Rosário (O Estado de S. Paulo), "como um dos melhores documentários da história do cinema brasileiro".

Naquele mesmo ano, a censura atingiu dois outros programas, coincidentemente ligados a intelectuais comunistas: uma novela do Dias Gomes e o especial "A enxada", baseada no conto de Bernardo Élis (de quem eu filmaria, em 1998, o romance O Tronco). Naquele momento, eu já estava com um pé fora da TV, voltando ao cinema.

Com a Embrafilme fiz, em 1977, Doramundo, cujo primeiro roteiro foi escrito pelo Vlado. Em 1978, o filme foi o vencedor do Festival de Gramado (Melhor Filme/Melhor Diretor), prêmios que dediquei ao meu querido amigo assassinado pela ditadura militar. Fiz também com a Embrafilme alguns outros filmes: O homem que virou suco(1981), A próxima vitima(1982-83) e O país dos tenentes(1987).

São produções extremamente ligadas ao momento político, mesmo que eu não procurasse isso nem tentasse qualquer didatismo, como aliás observam os textos da curadoria de minha mostra recente na sala da Fundação Banco do Brasil, em São Paulo. Mas é inegável que a escolha dos temas e os tratamentos mostravam que minha cabeça e minha emoção pendiam para uma busca de resposta aos desafios do momento. Era a busca de um cinema ficcional, onde os personagens se criariam e se desenvolveriam em meio a conflitos fundamentais de cada momento da vida brasileira.

Em O bomem que virou suco, por exemplo, é a busca da identidade própria do personagem feita pelo genial José Dumont, justamente contra a identidade imposta a ele. E nós estávamos em 1979, quando filmei o ano da anistia e das greves no ABC.

A próxima vítima passa-se exatamente no momento das eleições de 1982 e mostra que os discursos da oposição já estavam atrasados diante da degradação social da vida brasileira, que o filme expõe até mesmo anunciando o que viria depois: a incrível violência que fez ele próprio se confundir com os noticiários, um ano depois, durante seu lançamento. 
O país dos tenentes, que os militares não queriam que eu filmasse, pressionando a mim e ao ator Paulo Autran, fala do momento da transição para a democracia, vendo-o como o final de um ciclo onde as idéias haviam sido corrompidas pela aproximação com o poderoso Estado brasileiro. Paulo Autran vivia o velho general da Reserva, exrevolucionário de juventude e, agora, relações públicas de uma multinacional. Em plena transição política para a democracia, o velho general sentia a proximidade da morte. Ainda vivo, sentia-se apodrecido, corrompido, o corpo muitas vezes coberto de insetos. Enquanto isso, seu próprio filho, um jovem oficial, costurava um novo pacto com uma multinacional, garantindo-lhe o espaço no novo regime.

Em 1990, ainda com a Embrafilme, eu preparava meu novo filme, precisamente sobre a história de Vladmir Herzog, uma co-produção com a Espanha (TV Espanhola), Iugoslávia (que produziria as filmagens da infância de Vlado durante a Segunda Guerra) e Portugal (Instituto Português de Cinema). E trocava correspondências com o grande ator Klaus Maria Brandauer (Mephisto), que conheci no FestRio (Festival Internacional do Rio de Janeiro, em 1987), para o papel de Vlado. Veio o Collor e jogou tudo por terra: bloqueou os recursos do filme. E acabou com a Embrafilme e o Concine, num gesto oportunista, acenando para o liberalismo, mas dando uma satisfação fácil às críticas generalizadas contra as instituições do cinema brasileiro, em vez de procurar entender a necessidade de avançar a partir dos modelos penosamente construídos.

Não só a minha carreira, ascendente em termos internacionais, sofreu um duro revés: o cinema brasileiro praticamente morreu naquele ato irresponsável de um governante que duraria pouco, vitimado pela sua própria irresponsabilidade, mas que teve tempo ainda de causar esse imenso mal ao nosso cinema. De certa forma, esse momento marca o fim de uma longa etapa do cinema brasileiro. Para mim, em particular, marca o fim de um período de estreita e quase obrigatória ligação de meu cinema com o momento político, o sentimento sempre voltado para o fim do regime militar, derrubado pelo movimento democrático em 1985.

O efeito Collor me fez ficar oito anos sem filmar. Só voltei em 1996, com O cego que gritava $l u z$, seguido de $O$ tronco (1998) e, agora, $R$ na $6, s / n$., filmes em que ainda busco temas ligados às questões políticas e sociais brasileiras, mas já não há urgência, substituída agora por uma certa descrença incômoda que julgo ser preciso cultivar por algum tempo. 


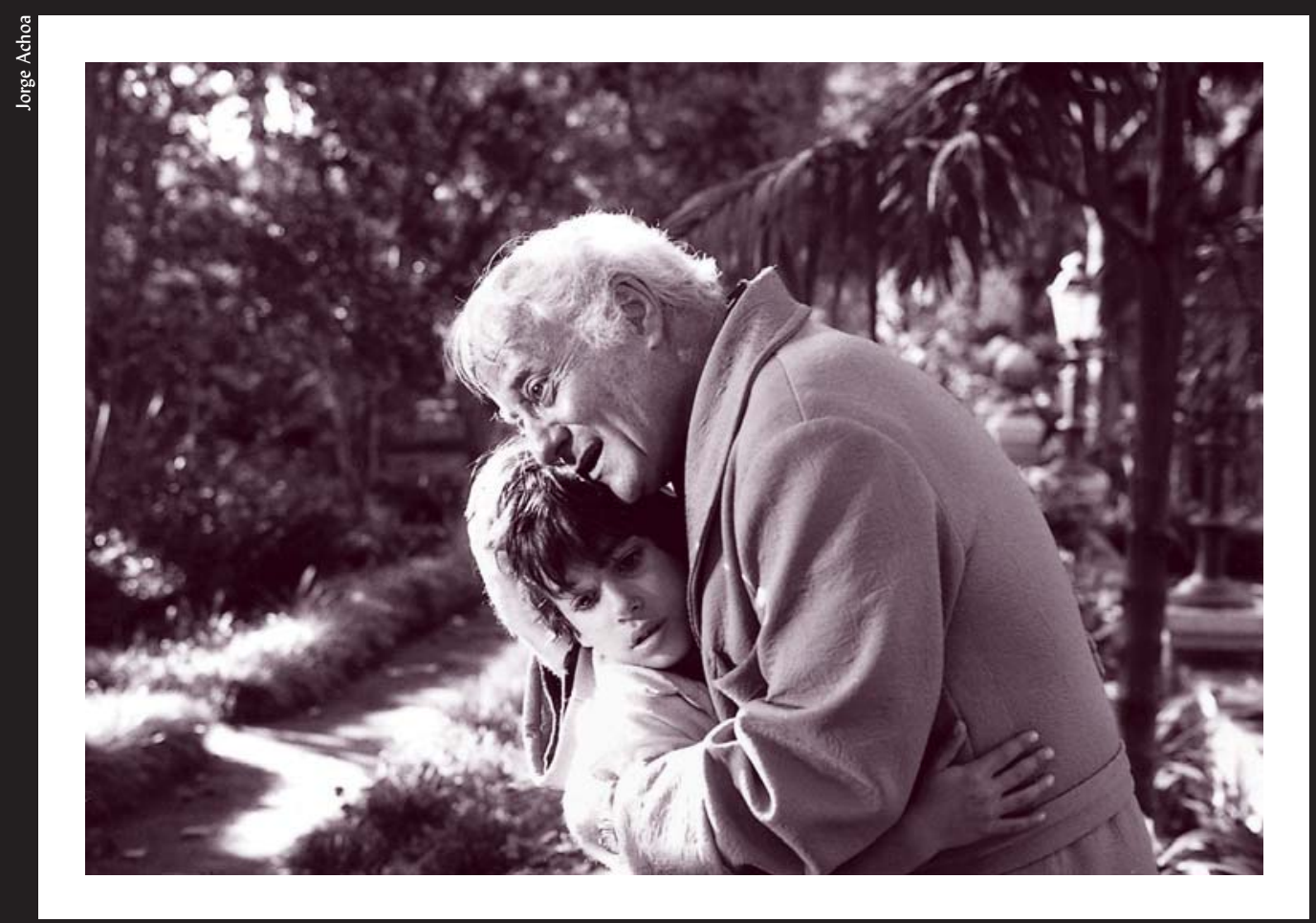

Paulo Autran em O país dos tenentes (1986): a emoção a serviço da narrativa épica.

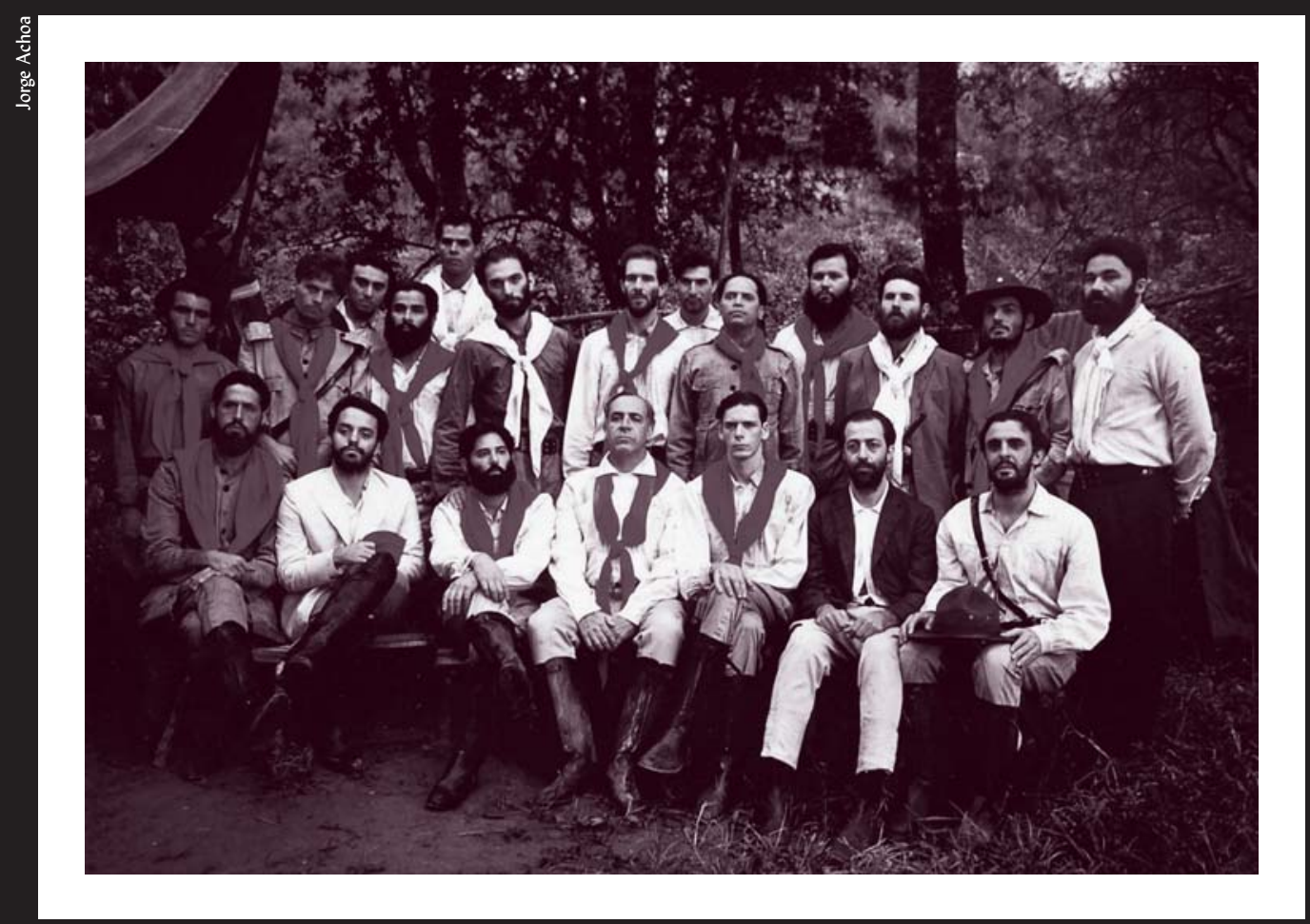

Tenentes de Prestes: a reconstituição histórica. 


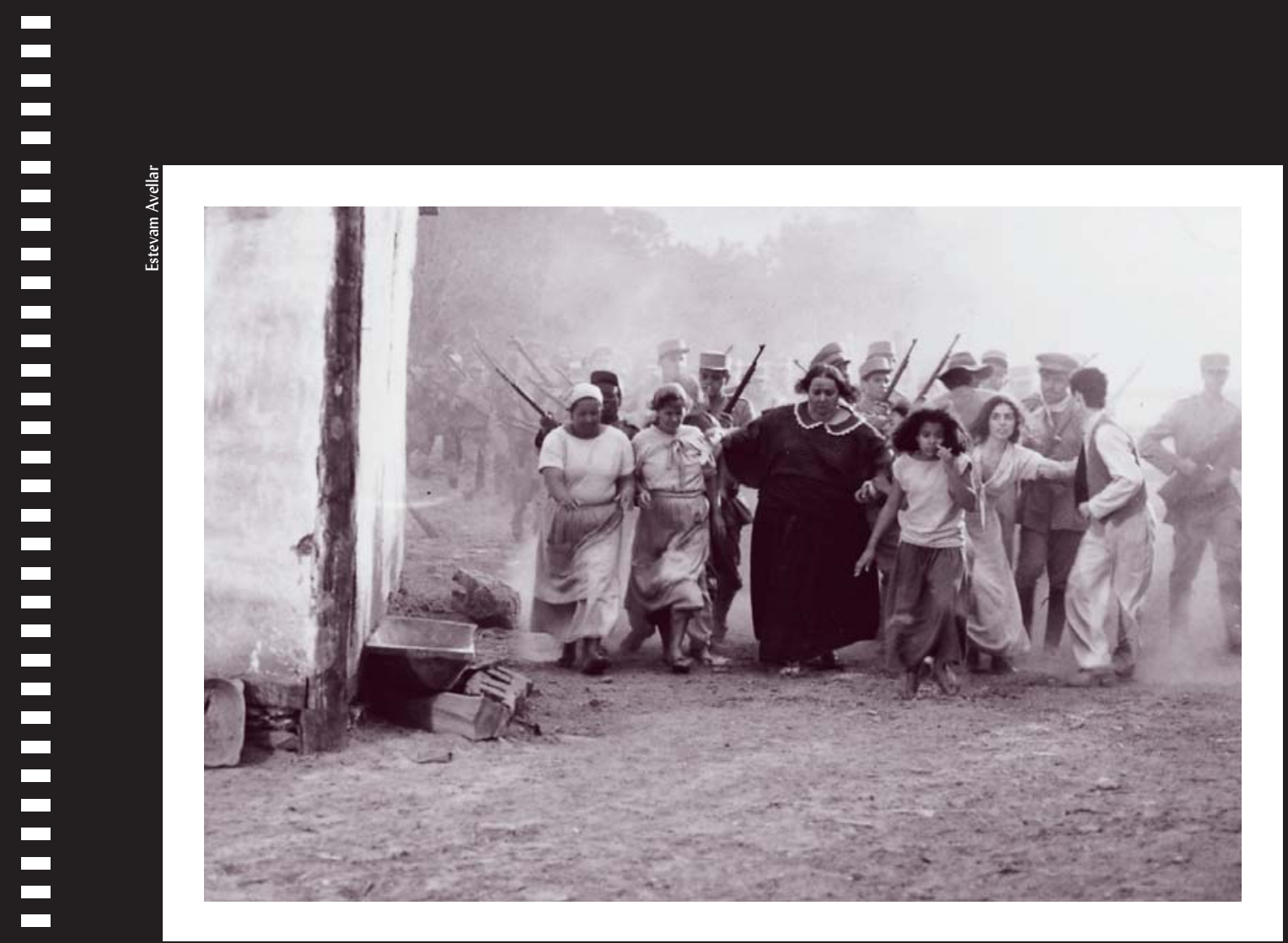

O tronco (1999): adaptação do romance de Bernardo Élis, baseado em fatos reais.

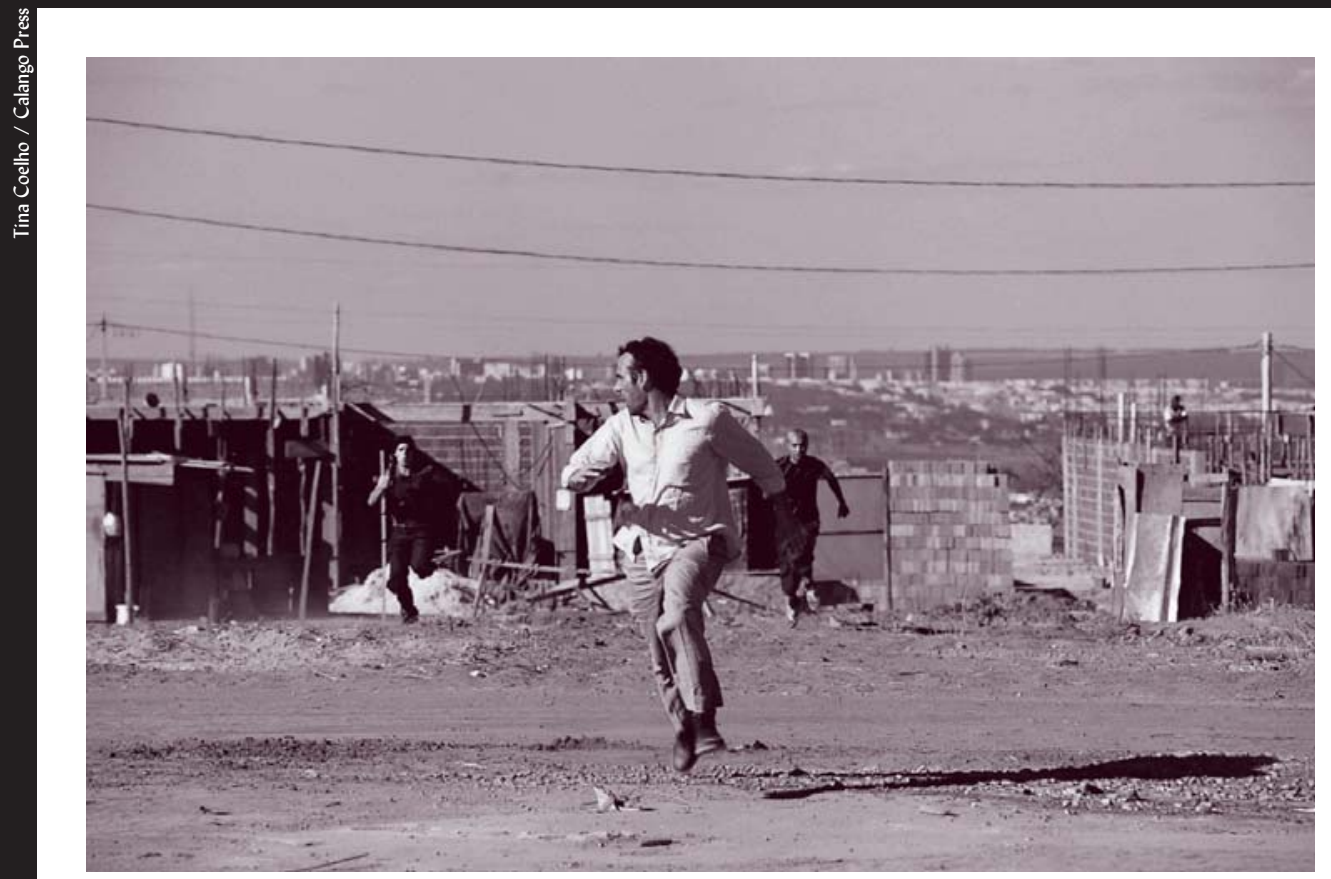

Marco Ricca: a fuga na paisagem áspera da periferia de Brasilia em Rua 6, s/n. (2002). 
O cinema brasileiro, tentando se reerguer, foi buscar novos modelos de produção, descentralizando decisões principalmente por meio das leis de incentivo fiscais. Aos poucos, de forma saudável, vamos fugindo dessa marca pesada da minha própria geração, a marca de certa forma militante, de quem sabe que pensar e criar representam sempre, para os regimes autoritários, um perigoso exercício político. O cinema brasileiro se diversifica e se renova de forma surpreendente, apesar das dificuldades. Surgem novos valores, novas idéias, lideranças e tendências. Temos hoje um cinema quem sabe mais livre, mais diversificado, mais sem donos, quebrando a idéia (importante para a época) de um cinema hegemonizado por um pequeno grupo de heróicos e geniais cineastas dos anos de 1960. Falta, agora, reconquistar o público perdido, em meio a tantos problemas e reveses.

Pirenópolis, Goiás, 13 de setembro de 2002.

João Batista de Andrade, diretor e produtor de filmes e documentários para o cinema e para a televisão, é doutor em Cinema pela Escola de Comunicações e Artes da USP, e autor do livro O povo fala (Editora Senac). 